\title{
NUORTEN MIESTEN KIRJEITSE OHJAILEMAT SEURUSTELUSUHTEET 1800-LUVUN LOPUN SISÄSUOMALAISELLA MAASEUDULLA
}

\author{
Pasi Saarimäki
}

Reilut sata vuotta sitten suomalaisella maaseudulla eläneiden naimattomien miesten ja naisten seurustelusuhteet olivat sidoksissa unelmiin ja suunnitelmiin tulevasta avioliitosta. Toisiinsa kiintyneiden nuorten tapailemiseen on aiemman tutkimuksen mukaan liittynyt yhteisöllistä ja yhteiskunnallista avioliittoon kiinnittyvää normatiivisuutta: vakiintuneemman seurustelun tuli johtaa nopeassa tahdissa kosintaan, kihlautumiseen ja häiden viettoon. Tätä tutkimuksellista lähtökohtaa lähden tarkentamaan siitä lähdeaineistollisesta näkökulmasta, että kaikki seurustelusuhteet eivät johtaneet avioliittoon. Tarkastelen tässä artikkelissa sisäsuomalaisessa Keuruun käräjäkunnassa 1800-luvun lopulla eläneiden nuorten miesten ja naisten seurustelusuhteiden kehittymistä kohti avioliittoa ja sitä, kuinka tälle tielle alkoi kasautua ongelmia. Tutkin tätä kehitystä suhteiden sisältä käsin, miesten seurustelukumppaneilleen lähettämien kirjeiden avulla. Intiimin ajatuksenvaihdon tarkastelu täydentää aiemman tutkimuksen rakentamaa kuvaa entisajan inmisten parinmuodostuksesta sekä syventämällä että monipuolistamalla näkemystämme menneistä parisuhteista.

Avioitumista edeltävän seurustelun historiallinen tutkimus on melko nuorta. Englantilaiset Edward Shorter (1975) ja Lawrence Stone (1979) olivat ensimmäisiä, jotka ottivat seurustelun tarkemman tutkimuksen kohteeksi. He kiinnittivät huomiota erityisesti esiaviollisiin raskauksiin, puolisonvalinnan perusteisiin ja muiden perheenjäsenten rooliin avioliitosta päätettäessä. Nämä teemat ovat ohjanneet seurusteluhistorian kysymyksenasettelua näihin päiviin asti. (Ks. Gillis 1985; Darrow 1985; van Bavel 2001.) 
Pasi Saarimäki: Nuorten miesten kirjeitse ohjailemat seurustelusuhteet 1800-luvun lopun sisäsuomalaisella maaseudulla

[http://www.elore.fi/arkisto/2_14/saarimaki.pdf]

Historiallisessa seurustelututkimuksessa käydyn keskustelun voi kiteyttää siten, että mitä kauemmas 1900-luvulta menneisyyteen päin kuljetaan, sitä merkittävämmäksi kasvaa vanhempien, perheenjäsenten ja sukulaisten rooli avioliitosta päätettäessä. Avioliitto oli länsimaissa alun perin sukujen ja myöhemmin perheiden välinen sopimus. (MacFarlane 1986, 119-147; Gaunt 1996, 19-27.) Puolisonvalintaan vaikuttivat erilaiset tekijät, jotka vaihtelivat sosiaaliluokittain. Avioliittoa solmittaessa tuli ottaa huomioon taloudelliset perusteet, esimerkiksi osapuolten työkyky tai varakkuus, ja sosiaaliset perusteet: puoliso valittiin yleensä samasta sosiaaliluokasta tai säädystä. (Stone 1979, 181-183; Bjurman 1998; Backman 2006; Dribe \& Lundh 2009, 388-391.) Puolisoehdokkaiden oma päätäntävalta oli rajallinen, ja erityisesti luonteiden keskinäistä sopivuutta, kiintymystä ja rakkautta pidettiin toissijaisina perusteina avioliitolle (esim. De Munck 2004; Dribe \& Lundh 2009).

Miesten ja naisten oma päätäntävalta ja keskinäiset tunteet nousivat ylemmissä yhteiskuntaluokissa tärkeämpään rooliin 1700-luvulta lähtien (Stone 1979, 184-216; Lystra 1989; Bjurman 1998; Backman 2006; King 2010). Kaupunkilais- ja maaseuturahvaan parissa tätä muutosprosessia on tarkasteltu vähemmän (esim. Shorter 1975, 120, 148-157, 161, 165167; King 2010), mutta 1800-luvun lopun suomalaisella maaseudulla nuoret hakivat seurustelukumppaneitaan myös omaehtoisesti (Heikinmäki 1981, 52, 59-64; Raitasalo 2004, 124-125, 140-142). Persoonallisella kiintymyksellä oli täten tärkeä sijansa aikakauden puolisonvalinnassa. Kirjeenvaihdossa olleiden miesten ja naisten keskinäisillä tunteilla ja kirjeitse esitetyillä tunteenilmaisuilla oli tärkeä merkitys seurustelusuhteen eri vaiheissa.

Suomalaiset historiantutkijat eivät ole tutkineet seurustelua paljonkaan. Aihetta on lähestytty epäsuorasti avioliiton muodostamisen oikeudellisia muotoja, esimerkiksi kihlausta ja vihkimistä, tutkien. (Knuutila 1990; Korpiola 2009.) Jos historioitsijat ovat tarvinneet taustatietoa seurustelusta, he ovat yleensä viitanneet seurustelu- ja häätapoja kartoittaneeseen kansatieteelliseen tutkimusperinteeseen. Kyseisessä "naimatapakirjallisuudessa" on vertailtu esimerkiksi alueellisesti vaihdelleita avioliitonmuodostamistapoja, tarkasteltu seurustelun ja avioliiton solmimisen vuodenaikoja sekä tutkittu avioliittokelpoisuuden edellytyksiä. (Lukkarinen 1933; Wikman 1937; Sarmela 1969; Heikinmäki 1981; Sarmela (toim.) 1981.)

Folkloristinen tutkimus tarjoaa tietoa siitä, millaiset olivat suomalaisten maaseutuyhteisöjen käsitykset parinvalinnan ja seurustelun soveliaista tavoista. Suomalaisessa folkloristiikassa maaseudun nuorten seurustelua ja avioitumista on vähintäänkin sivuttu silloin, kun tutkijat ovat tarkastelleet perhettä, sukupuolta, ruumiillisuutta ja seksuaalisuutta. (Nenola \& 
Pasi Saarimäki: Nuorten miesten kirjeitse ohjailemat seurustelusuhteet 1800-luvun lopun sisäsuomalaisella maaseudulla

[http://www.elore.fi/arkisto/2_14/saarimaki.pdf]

Timonen 1990; Apo 1995; Pöysä 1997; Pöysä \& Siikala 1998; Apo ym. 1998; Stark-Arola 1998; Vakimo 2001; Kupiainen, 2004; Tarkka 2005.) Folkloristisessa tutkimuksessa on tulkittu folkloren ilmaisemia kansan ajattelutapoja ja kiteytyneitä arvoja. Perinteen on katsottu välittäneen, rakentaneen ja vahvistaneen yhteisön pitkänkin ajan kuluessa kiteytyneitä normeja, joiden avulla jäsenet sosiaalistettiin yhteisöönsä. (Esim. Nenola 1990, 12-13; Pöysä 1997, 21, 137; Tarkka 2005, 12, 221-222.) Tämän tutkimuksen kannalta folkloristinen tutkimus tarjoaa tietoa siitä, millaiset olivat suomalaisten maaseutuyhteisöjen käsitykset parinvalinnan ja seurustelun soveliaista tavoista.

Tutkin tässä artikkelissa sitä, a) mitä kirjeet paljastavat aikakauden seurustelusuhteista ja seurustelukulttuurista, b) millaisten tunteenilmauksien ja asiasisältöjen avulla miehet edistivät seurustelusuhdetta kohti avioliittoa ja c) mikä merkitys kirjeillä oli suhteen eri vaiheissa. Kirjeet mahdollistavat myös suhteiden loppuvaiheiden ja konfliktien arvioinnin. Aiemmassa suomalaisessa ja kansainvälisessä historiallisessa seurustelututkimuksessa on tarkasteltu verrattain vähän seurusteluajan ongelmia ja suhteiden päättymistä, joten voin esittää näiltä osin aivan uudenlaista tutkimustietoa. Arvioin sitä, d) miksi suhteet kaatuivat ja e) miten miehet tunteiden tasolla suhtautuivat naisen raskauteen ja syntyvään lapseen, f) millaisia aiheita he suhteen Ioppuvaiheen kirjeissä nostivat esiin. Esitän, että miehet pyrkivät kirjeiden avulla aktiivisesti ohjaamaan suhdetta sen eri vaiheissa. Toisin sanoen kirjeet olivat miehille väline, jolla he sekä ohjasivat suhdetta kulttuuristen odotusarvojen mukaisesti kohti avioliittoa että reagoivat myöhemmin suhteen kohtaamiin haasteisiin.

Artikkelini liittyy kansanihmisten kirjoittamia tekstejä tarkastelevaan, monitieteiseen tutkimuskenttään (esim. Makkonen 2002; Lyons (ed.) 2007; Laitinen \& Mikkola (toim.) 2013; Kuismin \& Driscoll (eds.) 2013) ja siihen liittyvään, Martyn Lyonsin nimeämään New history from below tutkimukseen, jolla tarkoitetaan historian tutkimista alempien luokkien itse tuottamista dokumenteista käsin (Lyons 2013, 14-21). Maaseudun kansanihmiset olivat itseoppineita tai vähän koulutusta saaneita, minkä vuoksi he erottuivat aatelistosta, porvaristosta ja oppisivistyneistöstä. Kirjoitusten avulla on mahdollista tarkastella heidän käsityksiään ja kokemuksiaan omasta elämästään. Kansanihmisten näkökulmat tarjoavat tuoreen näkökulman laajempiin historiallisiin prosesseihin. (Keravuori 2012, 24-27; Kauranen 2013, 22-26.) 
Pasi Saarimäki: Nuorten miesten kirjeitse ohjailemat seurustelusuhteet 1800-luvun lopun sisäsuomalaisella maaseudulla

[http://www.elore.fi/arkisto/2_14/saarimaki.pdf]

\section{TUNTEITA KOSKEVIA LAUSUMIA}

Käytän tutkimusaineistona seurustelunaikaisia yksityiskirjeitä, jotka ovat säilyneet osana talvi-, syys- ja välikäräjien varsinaisasiain pöytäkirjoja eli oikeuspöytäkirjoja. Tutkimusalueenani on Keuruun käräjäkunta, jonka muodostivat 1800-luvun lopussa sisäsuomalaiset Keuruun, Multian ja Pihlajaveden pitäjät. Olen löytänyt kirjeitä seitsemän oikeustapauksen yhteydestä vuosilta 1889-1899. Viidessä lapsenelatustapauksessa ja yhdessä lapsenmurhatapauksessa naimaton mies oli lähettänyt kumppanilleen kirjeitä. Vertailumateriaalina on yksi tapaus kihlalahjojen palauttamisesta, jonka yhteydessä tarkasteltiin naisen miehelle lähettämää kirjettä. Kaikki kirjeet olivat suomenkielisiä. Enimmillään kirjeitä löytyi yhden oikeustapauksen yhteydestä neljä kappaletta, ja yhteensä käytössäni on ollut 13 yksityiskirjettä. ${ }^{1}$ Toisinaan kirjuri oli kopioinut kirjeiden sisällöt pöytäkirjan sivuille, eikä alkuperäisiä kirjeitä ole saatavilla, mutta useimmiten alkuperäiset kirjeet ovat säilyneet pöytäkirjasidoksessa erillisenä liitteenä.

1800-Iuvun Iopun oikeuspöytäkirjat ovat hedelmällinen lähdeaineisto maaseudun ihmisten sosiaalisten suhteiden ja ristiriitatilanteiden tutkimisessa, sillä tuomari ja lautamiehistö tarvitsivat yksityiskohtaisia suullisia tai kirjallisia lausuntoja asianosaisilta henkilöiltä ja ulkopuolisilta todistajilta. Esimerkiksi lapsenelatustapauksissa oikeus halusi saada selville, oliko mies ollut seksuaalisessa suhteessa naiseen siihen aikaan, kun raskaus oli saanut alkunsa. (Saarimäki 2010, 24-28.) Naisten oikeuden luettavaksi tuomat kirjeet olivat raskauttavia todisteita seurustelusuhteista.

Kirjeenvaihdon osapuolet olivat tyypillistä aikakauden sisäsuomalaista tilatonta maaseutuväestöä (Vihola, 1983; Mönkkönen 1983). Yhdessä tapauksessa kyseessä olivat renki ja piika, toisessa torpparinpoika ja itsellinen, kolmannessa torppari ja talontytär, neljännessä talollisenpoika ja suntiontytär, viidennessä torpanpoika ja itsellisentytär, ja kuudennessa molemmat olivat itsellisiä. Muutamissa tapauksissa elämä oli sidoksissa teolliseen elinkeinoon. Paikallisen tehtaan piirissä työskentelivät edellä

\footnotetext{
1 Lapsenelatustapauksissa aviottoman lapsen synnyttänyt nainen haki käräjien kautta elatusvelvollisuutta lapsensa isäksi väittämälleen miehelle (ks. Bolin Hort 1997, 50-65; Saarimäki 2008, 156-160; Saarimäki 2010, 25-28, 155-161, 167-173). Lapsenmurhatapauksessa nimismies syytti itsellisentytärtä ja tämän raskaaksi saattanutta miestä lapsenmurhasta. Kihlalahjojen palauttamistapauksessa, kihlauksen purkamisen jälkeen, mies vaati entistä kihlattuaan palauttamaan tälle lahjoittamansa kihlajaislahjat. Taustoittavassa roolissa käytän yhtä lastenelatustapausta ja yhtä tapausta avioliiton täyttämisestä, toisin sanoen tapausta, jossa tarkasteltiin pitäisikö oikeuden velvoittaa vihkimistään viivytelleet kihlaparit avioliittoon. Kyseiset tapaukset syventävät naimattomien miesten ja naisten välisen seurustelun sekä tunteiden ilmaisun tutkimista. Artikkelissa käytettävä lähdeaineisto on osa laajempaa, väitöskirjaani varten Keuruun käräjäkunnasta vuosien 1880-1900 osalta keräämääni oikeusaineistoa. (Saarimäki 2010.)
} 
Pasi Saarimäki: Nuorten miesten kirjeitse ohjailemat seurustelusuhteet 1800-luvun lopun sisäsuomalaisella maaseudulla

[http://www.elore.fi/arkisto/2_14/saarimaki.pdf]

mainituista henkilöistä suntiontytär ja piika. Seitsemännessä tapauksessa henkilöt työskentelivät suhteensa aikana Mäntän paperitehtaassa. Heidän sosioekonominen taustansa - tullitarkastaja ja tehtaantyöntekijä - erosi hieman muista.

Maantieteellinen etäisyys oli motivoinut kirjeiden kirjoittamista. Pariskunnat eivät asuneet samassa taloudessa, joten päivittäinen tapaaminen ei ollut mahdollista. Toisinaan he asuivat samassa kylässä, joskus taas vielä kauempana toisistaan. Muutamassa tapauksessa oli kyse hallinnollisesta etäisyydestä: esimerkiksi Wilhelmina L. sai kirjeen Abraham L:Ita ollessaan tutkintovankeudessa lapsenmurhasta syytettynä. Yleensä kolmannet osapuolet kuljettivat pyynnöstä kirjeet vastaanottajille.

Yksittäisiä kirjeitä tulisi tarkastella aina osana laajempaa kirjeenvaihdon kokonaisuutta. Historiantutkimuksen haasteena on kuitenkin se, että käytössä olevat kirjekokoelmat ovat usein sirpaleisia. (Lahtinen ym. 2011, 19-20.) Tarkastelemani kirjeet ovat seurustelusuhteista kertovia yksittäisiä fragmentteja: kaikki miesten lähettämät kirjeet eivät ole säilyneet, eikä toisen osapuolen, naisten vastauskirjeitä ole ollenkaan käytettävissä yksittäistä vertailukirjettä lukuun ottamatta. Miesten kirjeissä löytyy naisten lähettämien kirjeiden sisällöstä jonkin verran viitteitä, joista esitän suoria lainauksia. Niistä käy ilmi, että parisuhteiden edistäminen ei ollut pelkästään miesten aktiivisuuden varassa. Lähdeaineiston luonteesta riippuen artikkelissa keskitytään kuitenkin miehiin.

Sisäsuomalaisten miesten jälkeensä jättämä kirjeaineisto on määrällisesti verrattain pieni, mutta tutkimuksellisesti sitäkin kiinnostavampi. Kyseiset kirjeet ovat päätyneet oikeudenkäyntien todistusaineistoksi, koska niissä korostuivat parisuhteen muodostaminen ja suhteen myöhemmät ongelmat. Näin on mahdollista arvioida sitä, miten miehet kirjeiden avulla yrittivät ohjata suhdetta sen eri vaiheissa, ja miten miehet reagoivat suhteen haasteisiin.

Kirjeaineiston määrällisestä pienuudesta johtuen joudun joissain artikkelin osioissa tukeutumaan vain muutamaan aihetta käsittelevään kirjeeseen. Valtaosa aineistostani on ajanjaksolta, jolloin suhteet etenivät kohti loppuaan, joten artikkelin loppuvaiheessa kirjeitä on käytettävissä tutkimuskysymyksiin vastaamisessa useampia. Tätä epäsuhtaa korjaan käyttämällä oikeuspöytäkirjojen muuta sisältöä taustoittamaan kirjeiden antia. Asianosaisten ja todistajien oikeuden edessä antamat lausunnot auttavat kirjeiden sisällön tulkitsemisessa ja helpottavat niiden sijoittamista tiettyyn suhteen vaiheeseen.

Kirjeiden kirjoittaminen vaati luku- ja kirjoitustaitoa. Kirkon järjestämän alkeisopetuksen ja rippikouluun liittyvän kristillisen opin osaamisvaatimusten vuoksi suomalainen maalaisrahvas osasi 1800-luvun puolivälin jälkeen 
Pasi Saarimäki: Nuorten miesten kirjeitse ohjailemat seurustelusuhteet 1800-luvun lopun sisäsuomalaisella maaseudulla

[http://www.elore.fi/arkisto/2_14/saarimaki.pdf]

lukea vähintäänkin välttävällä tasolla, mutta kirjoitustaito oli harvinaisempaa. (Leino-Kaukiainen 2007; Laine \& Laine 2010, 258-296; Kauranen 2013, 30-38.) 1890-luvulla Keuruun käräjäkunnassa naimaiän saavuttaneiden elämässä luku- ja kirjoitustaidon opetteluun ei ollut ehtinyt olla paljonkaan mahdollisuuksia. ${ }^{2}$ Aineiston ainoa selkeästi koulutettu ja kirjoitustaitoinen henkilö oli lappeenrantalainen tullitarkastaja.

Miehet olivat kuitenkin ainakin jossain määrin kirjoitustaitoisia. Vain yhdessä tapauksessa käy suoraan ilmi, että kirjeen oli kirjoittanut pyynnöstä toinen osapuoli. Kirjeet olivatkin vähintään välttävän kirjoitustaidon hallitsevien miesten tapa viestiä saman taitotason omaaville seurustelukumppaneille. Kirjeitä lukiessa syntyy vaikutelma miehistä, jotka olivat kirjoittaneet hitaasti kamppaillen koko ajan taitojensa ylärajoilla. Joissakin kirjeissä miehet valittelivatkin huonoa kirjoitustaitoaan. Horjuva oikeinkirjoitus oli tyypillistä suomalaisille kansankirjoittajille (Keravuori 2012, 6263), mutta kielellisesti he pyrkivät seuraamaan aikakauden kirjakielen standardia (esim. Nordlund 2005, 60-63, 67-70). Yhteydenpito seurustelukumppaniin motivoi miehiä edelleen kehittämään kirjoitustaitoaan (Kauranen 2013, 46).

Kirjeet ovat yhdessä päivä- ja muistikirjojen, muistelmien, omaelämäkertojen ja matkakertomusten kanssa niin sanottuja egodokumentteja: kirjoituksia, joissa tekijä kirjoittaa omista teoistaan, ajatuksistaan ja tunteistaan (Keravuori 2012, 10-21). Ne eivät kuitenkaan kerro ihmisistä, tunteista ja ajatuksista sellaisinaan. Kirjeen kirjoittaja luo tietoisesti ja kulttuuristen mallien ohjaamana toiselle suunnatun ymmärrettävän kuvan ja tarinan itsestään.

Tunteenilmaisut ovat kirjeissä merkittävässä roolissa. Varsinkin suhteiden alkuvaiheen kirjeitä voi luonnehtia rakkauskirjeiksi: niistä löytyy runoja ja muistovärssyjä, ja esimerkiksi puhuttelusanat ja lopputervehdykset ovat tunteellisia. (Hökkä 2010, 127.) Vastaavanlaista avointa tunteista kirjoittamista voi löytää myös suomalaisten maaseudun miesten päiväkirjoista. Niiden pitämisen kimmokkeena oli usein rakastuminen tai rakkauden menettäminen, ja kirjoittaminen oli tällöin kanava purkaa tunteita. (Makkonen 2002, 167-177; Kauranen 2009, 11-16, 89, 92-123, 179, 181-206.)

Vaikka rakkaus voidaan historiattomalla psykologisella tasolla määritellä toiseen ihmiseen kohdistuvaksi, voimakkaan fyysiseksi ja persoonalliseksi

\footnotetext{
2 Keuruulla, Pitäjävedellä ja Multialla oli ollut 1870-luvulta asti käytössä kiertokoulujärjestelmä, joka tarjosi perustiedot varsinaista kansakoulua varten. Pitäjissä oli tarkasteluaikana vain muutama kansakoulu. Vain osa kouluikäisistä kävi kiertokoulua 1800-luvun lopussa, Keuruulla ja Pihlajavedellä keskimäärin joka kolmas, Multialla vielä harvempi. Lisäksi oppilaat olivat usein opetuksesta poissa, eivätkä opettajat heidän taitojaan kehuneet. (Vihola, 1983, 348-370; Mönkkönen 1983, 212-224, 232-233.)
} 
Pasi Saarimäki: Nuorten miesten kirjeitse ohjailemat seurustelusuhteet 1800-luvun lopun 7 sisäsuomalaisella maaseudulla

[http://www.elore.fi/arkisto/2_14/saarimaki.pdf]

kiintymyksen tunteeksi, rakkaus laajemmassa merkityksessään on historiallisesti ja kulttuurisesti vaihteleva ilmiö. Tunteiden edellytykset, niille annetut merkitykset ja tunteiden ilmaisemisen tavat ovat kehystäneet eri historiallisina aikoina subjektiivista tunnekokemusta (esim. Gillis 1988; Jarrick 1997, 9-10, 15-16; Kietäväinen-Sirén 2011). Kansankirjoittajat hyödynsivät kirjoituksissaan oman ympäristönsä ja suullisen perinteen käsityksiä sekä kirjallisen kulttuurin vaikutteita. Suullisessa kansanperinteessä tunnekäsitteistöä tarjosivat esimerkiksi kansanlaulut, balladit, sananlaskut ja lemmennostoloitsut (Jarrick 1997, 164, 241-242; Hakamies 1998; Stark-Arola 1998).

Varsinkin kansainvälisessä tutkimuksessa on korostettu sitä, kuinka 1800luvun lopulla ylempien säätyjen ja sivistyneistön keskuudessa keskinäisten tunteiden tärkeys puolisonvalinnassa kasvoi. Sisäsuomalaisilla miehillä oli kytkös tähän porvarilliseen rakkauskulttuuriin ainoastaan sattumanvaraisesti levinneiden kulttuurituotteiden - esimerkiksi miehen ja naisen välisistä tunteista kertovien arkkiveisujen (Huhtala 1996, 238-246, 240; Hakapää 2013), tai rakkauskirjeitä käsittelevien kirjeoppaiden (LeinoKaukiainen 2011, 211-214) - välityksellä, joista naimattomat miehet mahdollisesti olivat ammentaneet tunnekäsitteistöään. Toisaalta aineksia on voitu saada myös kirjojen, seuranäytelmien ja erityisesti sanomalehdistön välittämästä kaunokirjallisuudesta, jossa rakkaussuhteet ja niiden ongelmat olivat yleisiä aiheita. Itseoppineet kirjoittajat laativat itsekin romanttisia novelleja ja näytelmiä. (Esim. Tommila 1979; Laitinen 2013; Seutu 2013.)

Emotionologia tarjoaa hedelmällisen lähestymistavan tutkimusaineistoni tulkintaan. Se ei yritä tavoittaa menneisyyden ihmisten tunnekokemusta, vaan on kiinnostunut erityisesti tunteiden ilmaisemisen kielelliskulttuurisia muotoja kontrolloivista tunnesäännöstöistä, tunnestandardeista. Sosiaalinen ympäristö on aina asettanut tarkat säännöt rakkauden ilmaisuille. (Stearns \& Stearns 1985, 813-815, 824-829; Korhonen 2002, 59-60.)

Analysoidessani kirjeitä en ota kantaa siihen, kuinka todenperäinen tunne kirjoittajan mielessä oli, joskaan en lähtökohtaisesti tunteiden aitoutta epäile. Tunnetta ja siitä kertomista ei voi pitää automaattisesti samana asiana, sillä kirjallinen tunteen ilmaus oli samalla osa ajan sosiaalisia käytäntöjä. (Bound 2002, 5.) 1800-Iuvun lopun maaseudun naimattomat miehet ja naiset tiedostivat kulttuurisesti hyväksytyt tavat osoittaa romanttista rakkautta, puhua ja kirjoittaa siitä, ja nämä ilmaukset ymmärrettiin oleellisena osana avioliittoon johtavaa seurustelua. Ilmaisut ovat tällöin William Reddyn sanoin emotiiveja eli tunteita koskevia lausumia, joilla tunteiden ilmaisemisen ja tiedonvälityksen ohella myös 
Pasi Saarimäki: Nuorten miesten kirjeitse ohjailemat seurustelusuhteet 1800-luvun lopun sisäsuomalaisella maaseudulla

[http://www.elore.fi/arkisto/2_14/saarimaki.pdf]

muotoiltiin kyseisiä tunteita. Ilmaisuilla siis saatiin jotain aikaan, ja Reddyn käsitteen taustalla onkin J. L. Austinin lingvistinen puheaktiteoria ilmaisuista, jotka kuvaavat todellisuutta tai toteuttavat jotain todellisuudessa. Emotiivit sijoittuvat näiden välimaastoon: ne ovat yhtä aikaa tunteen ilmaisuja ja muokkaajia. Emotiivien välityksellä voidaan esimerkiksi rakentaa tunteita, piilottaa tai tehostaa niitä. (Reddy 1997, 330-331, 333; Reddy 2001, x, 46-47, 322-323; Tepora 2012, 327-329.) Tunteita käsittelevillä lausumillaan 1800-luvun lopun maaseudun miehet samalla sekä ilmaisivat omia tunteitaan että osallistuivat tunnesuhteen ohjaamiseen sen eri vaiheissa.

Tarkastelen artikkelissani menneisyyden ihmisten intiimejä yksityisasioita. Reilu sata vuotta sitten eläneet ihmiset linkittyvät sukulaissuhtein vain muutaman sukupolven jälkeen nykypäivän keuruulaisiin, multialaisiin ja pihlajavetisiin. Tämä asettaa tutkimuseettisen haasteen. Millaisiin yksityiskohtiin aineistolainauksissa voi mennä? Onko ihmisten tunnistettavuudella merkitystä? Kunnioitan ihmisten intimiteettiä ja häivytän tunnistettavuuden viittaamalla suorissa lainauksissa pelkästään sosiaaliseen asemaan, etunimeen ja matronyymiin / patronyymiin. On kuitenkin muistettava, että monet tekstissä mainitut arkaluontoiset asiat ovat olleet ainakin jossain muodossa paikallisyhteisön tiedossa. (Keravuori 2012,41.)

Teknisten viittauskäytäntöjen lisäksi vastaan eettiseen haasteeseen tutkimusasetelmallani. En tarkastele yksityiskohtaisesti yksittäisten inmisten elämänkaaria, vaan arvioin intiimin yksityiselämän yleisiä piirteitä. Yksittäisten seurustelusuhteiden tai kirjeiden tarkastelun sijaan hajotan oikeudenkäyntien ja kirjeiden sisällön jäsennyksen raaka-aineiksi. Olen eritellyt erilaisia aikakauden seurusteluun liittyviä teemoja, jotka mahdollistavat suhteiden rekonstruoimisen kaareksi. Sen ensimmäisessä vaiheessa suhde etenee ja vahvistuu, ja jälkipuoliskolla se hajoaa. Suhteen kronologinen eteneminen muodostaa artikkelin rakenteen, ja kaaren eri vaiheissa tietyt pariskunnat nousevat suurempaan rooliin kuin toiset. En tarkastele intiimiä elämää tirkistellen tai tarkoitushakuisen provosoivasti, vaan lähestyn menneisyyden ihmisiä kunnioittavasti.

\section{TUNTEET JA TAPAAMISET SEURUSTELUN ALKUVAIHEESSA}

Suhteiden alkuvaiheessa miehet kirjoittivat avoimesti tunteistaan. Kirjoituksillaan miehet koettivat rakentaa ja ylläpitää suhdettaan naiseen, saamaan tämän vakuuttuneeksi tunteidensa aitoudesta. Kiihkeillä sanoilla ilmaistiin rakkautta ja vakuutettiin sitoutumista naiseen. (Frost 1995, 6566; Lystra 1989, 157-191.) 
Pasi Saarimäki: Nuorten miesten kirjeitse ohjailemat seurustelusuhteet 1800-luvun lopun 9 sisäsuomalaisella maaseudulla

[http://www.elore.fi/arkisto/2_14/saarimaki.pdf]

Esimerkiksi torpparinpoika Edvin Samuelinpoika aloitti kirjeensä itsellinen Edla Fredrikintyttärelle tunteitaan korostaen:

Hiljan tunetu ystäväväni Etla jota minä rakastan niinettä ei muita kettää ja nyt lähestyn minä teitä ällä pienelä ja halpa arvoisela kiereelä ja kiitoksija terveisistäne ja siitä kirjeestä jonka lähtiten minulen ja kyllä se oli hauska kirja.

Tämän jälkeen Edvin kiisti Edlan edellisessä kirjeessään esittämät epäilyt:

Mutta siitä oli minu pahamieleni kumanäi että etla epäilee että minä emmuista koskaa teitä mutta ei ystäväni seniinole kyllä minun oli niin ikävä että [...] minä meinasin päästä suusta suhun puhumaa teijäkanssa mutta elkää tykkäkö pahaa vaika minä en kirjotanu [...] ja kyllä minu oli ikävä ja paha mieleni kumminu tuloni jäi [...]. (JyMA Keuruun Sk 29.10.1896, § 266, liite Syhäst.)

Hyvästelyjen jälkeen Edvin lisäsi vielä "muistivärsyn":

Kuin lumi lahteleepi kaulasi valkeja / keveenä kohoilepi pojelesi karkeja

poskesipunata kuikakaksi mansikaa / huulesi luotu on muiskuja antama

äänesi vieno soisi kuin kirkkaslaseja / laulusi muistutaapi leivosen lauluva

Siiskuule ystäväni mun ajatukseni / ja sen saa sytänteni ja täytä toivoni.

(JyMA Keuruun Sk 29.10.1896, § 266, liite Syhäst.)

Kaipausta poissa olevaa inmistä kohtaan on pidetty romanttisen rakkauden ominaisuutena (Elomaa 1995, 41-42). Kirjeiden romanttisella rakkausdiskurssilla ylläpidettiin erossa olevien ihmisten suhdetta ja rakennettiin lupauksissa jatkuvuutta menneen ja tulevan välille. Romanttisen rakkauden tyypillisinä piirteinä on pidetty juuri etäisyyttä, erossa oloa ja saavuttamattomuutta. (Pehkonen 2013, 130-133, 135-136.) Kirjeissä korostuivat usein kaipauksen ja ikävän ilmaisut. Esimerkiksi otsikolla "Rakas ystävä" kirjeensä aloittanut torppari Kaarle Kaarlenpoika ilmaisi kaipauksensa heti ensimmäisillä riveillä:

Nyt toivon lähestyvä teitä Mutamalla ratilla ja saan kysyvä että mitä Teillen kuluu [...] ja tervesijä Tuhansia kuin yksin tällä ikävissän olen.

Kirjeen lopussa hän vielä korosti asiaa kirjaamalla epäilynsä, että "tokko te koskan minusta huolitte ja voika hyvin sitä toivotan Kaikella ystävytellä". (JyMA Keuruun Tk 19.2.1892, § 196, liite C.) Pelko tulla naisen hylkäämäksi saattoi olla osaksi naiselle osoitettua kohteliaisuusretoriikkaa, 
Pasi Saarimäki: Nuorten miesten kirjeitse ohjailemat seurustelusuhteet 1800-luvun lopun 10 sisäsuomalaisella maaseudulla

[http://www.elore.fi/arkisto/2_14/saarimaki.pdf]

mutta toisaalta myös miesten kokema aito tunne (Pohjola-Vilkuna 1995, 73).

Naisten lähettäessä miehille hellien tunteiden ilmaisuja sisältäviä kirjeitä nämä motivoituivat vastaamaan heille samalla tavalla. Esimerkiksi itsellinen Siviä Emanuelintytär oli lähettänyt omalle kihlatulleen, itsellinen Abelille kirjeen, joka alkoi pienellä muistivärssyllä ja jatkui kaipauksen ilmauksella:

Tuulella ei ole sydäntä että hän minun suruni ymmärätis että hän sanos minun kullallen ett ystäväs on niin suruinen [...] Arvoisa ystäväni; Kiiruusti riennän taasen luoksesi armahani, ei siis muutoin vaan ajatuksilla ja niillä nopein olen tykönäsi. (JyMA Keuruun Tk 7.4.1891, § 197.)

Kirjeiden välityksellä miehet eivät pelkästään ilmaisseet tunteitaan vaan pyrkivät tunteista kertomalla edistämään suhdetta kohti avioliittoa. Tällä tavoin he ohjasivat suhdetta vakiintuneempaan muotoon. Tunteilla he ilmaisivat naisille, että kyseessä oli jotain pysyvää ja ainutkertaista. Esimerkiksi renki Emil Kustaanpoika todisteli vakaita aikomuksiaan esittämällä kosiokirjeensä loppupuolella romanttisen tulkinnan siitä, mitä tuleva avioituminen merkitsisi, ja kuinka taloudellinen epävarmuus kestettäisiin. Emil toivoi, että Johanna tietäisi

valmistaa itsiäs ikuisen liiton tekemää, vaan älä sure neito nuori tämän maailman perää kun kaksi oikee sytämmet rakastaa toinen toistansa niin kyllä siin on Jumala rikkavutta antava. (JyMA Keuruun Sk 29.10.1895, § 248, liite kopare.)

Kirjeiden päämotiivina oli yleensä sopia tapaamisista. Tämä oli toinen kirjeiden sisällön teema, jota toistamalla miehet pyrkivät ohjaamaan suhdetta kohti avioliittoa. Esimerkiksi torppari Kaarle Kaarlenpoika kirjoitti Wilhelminalle:

[...] pyytän nöyrimmästi Että tulka manatai iltana sinne teijän navetan luokse ja jos on nin paha ilma että Emäs enin käykä sitten tistai Iltana. (JyMA Keuruun Tk 19.2.1892, § 196, liite C.)

Omalle kihlatulleen itsellinen Siviä Emanuelintytär kirjoittikin pitkästi juuri tapaamisista:

Miten hauskaa oli eilinen päivä minulle [...] Se olis hyvin hauskaa että me pääsisimme keskenäisiin puheisiin vähäki hetki että ei aina olisi häiritsiöitä, Hyvästi taasen tällä erää ja voi hyvin sano äitille terveesiä vaan ota itse enin. (JyMA Keuruun Tk 7.4.1891, § 197.) 
Pasi Saarimäki: Nuorten miesten kirjeitse ohjailemat seurustelusuhteet 1800-luvun lopun 11 sisäsuomalaisella maaseudulla

[http://www.elore.fi/arkisto/2_14/saarimaki.pdf]

Kirjeillä oli merkittävä tehtävä intiimin yksityisyyden luomisessa, sillä yöstelyä ${ }^{3}$ lukuun ottamatta naimattomilla miehillä ja naisilla ei arjessa ollut paljoakaan mahdollisuuksia kahdenkeskisille hetkille. Miesten ja naisten työt olivat yleensä vahvasti eriytyneet toisistaan, ja yhteisissä työtapahtumissa, esimerkiksi talkoissa ja työkisoissa, toista osapuolta oli useimmiten mahdollista nähdä ainoastaan muiden ihmisten läsnäollessa. (Saarimäki 2006, 41-45; Lukkarinen 1933, 70-86; Sarmela 1969, 110127.) Toiset ihmiset olivat läsnä myös kyläyhteisön lukuisissa vapaa-ajan tapahtumissa, kuten kristillisissä vuotuisjuhlissa tai nuorison omissa tilaisuuksissa, kuten kyläjuhlissa, markkinoilla tai kyläkeinuilla (Wikman 1937, 152-162; Sarmela 1969, 25-85, 128-154; Heikinmäki 1981, 5964).

Henkilökohtaiset tapaamiset olivat miehille tärkeitä. Toisinaan he kirjeissään korostivat yksinäisyyttään tai purkivat turhautumistaan siitä, etteivät nähneet rakastettujaan tarpeeksi usein. (Frost 1995, 66.) Tapaamisten odottamaton peruuntuminen oli pettymys, mutta aikataulujen yhteensovittamisen hankaluuksista kirjoittamalla miehet korostivat suhteen tärkeyttä. Suntiontytär Hulda oli lähettänyt talonpoika Viktor Obadiaksenpojalle kirjeen valittaen, ettei Viktor ollut tullut sovittuun tapaamiseen. Viktorin vastauskirjeen sävy oli katuva ja pahoitteleva. Hän kirjoitti kuinka aukaistuaan ja luettuaan kirjeen

et voi uskoa kuinka tulin pahoillen mielin kun sanoit olleesi ulkona niin kuinka puhuttiin [...] Ja sinä kysyt mikä oli syynä kun en tullu ja minä puhun toduden se oli minulla pahin syy kun oli hieman Liikutettu ja aina Enempi silloin kun piti lähtee minä ja akke käytiin ruukin puolella.

Anteeksipyyntö oikeutti Viktorin esittämään uuden tapaamispyynnön:

[...] jos vaan olis lauvantai iltana suotuisa ilma niin minä pydän jos lähtisit sinne hietalan tiellen siellä on niin tyyni ja rauhallinen. (JyMA Keuruun Tk 16.2.1899, § 149, liite Pajarista.)

Kirjeiden perusteella miehet saattoivat ottaa raskaasti sen, että nainen ei saapunut sovittuun tapaamiseen. Kesällä 1897 Viktor Obadiaksenpoika heittäytyi kirjeessään sentimentaaliseksi Huldan jätettyä tapaamisen väliin:

\footnotetext{
3 Yöstely - Keuruulla, Multialla ja Pihlajavedellä käytettiin käsitettä "yöstäminen" - oli maaseudulla kyläyhteisön yleisesti hyväksymä, avioliittoon johtavan tutustumisen tapa. Yöstelyssä saman kylän ripiltä päässeet naimattomat miehet kävivät yleensä viikonloppuisin, useimmiten kesäaikaan yksikseen tai isommalla porukalla iltamyöhään vierailuilla muusta talonväestä erillisiin tiloihin majoittuneiden nuorten naisten luona. Kansatieteellinen naimatapakirjallisuus on korostanut yöstelyyn liittyneen paljon sääntöjä esimerkiksi oikeantyylisistä ovien koputuksista aina siihen, mitä vaatteita on yöstelyn aikana luvallista riisua. (Lukkarinen 1933, 87-103, 108-116; Wikman 1937, 38-163; Sarmela 1969, 155180, 236, map 27: Night Courting of the Youth; Gaunt 1996, 23-30; Saarimäki 2006, 4548.)
} 
Pasi Saarimäki: Nuorten miesten kirjeitse ohjailemat seurustelusuhteet 1800-luvun lopun 12 sisäsuomalaisella maaseudulla

[http://www.elore.fi/arkisto/2_14/saarimaki.pdf]

\begin{abstract}
Ikävän tunteet vaikuttaa mielessäni minä tahdon kysyä mikä oli syynä kun ett tullu sinne johonka päätettiin minä kuljin yksin ja kaipasin sinua [...] yhdessä hetken aikaa kuljin herttaisessa ihanuudessa linnut lauloivat ja minä hiljalleen lauloin kanssa ja nautin vapautta ja toivoin nähdä sinutt mutta sinä olit niin kova sydämminen ettkä muistanu minua vaikka minä olin todella muistanu sinua aina. (JyMA Keuruun Tk 16.2.1899, § 149, liite Mänttä 18 3/6 97 Kesäkuuta.)
\end{abstract}

Kertoessaan kirjeissään yksityiskohtaisesti kokemastaan pettymyksestä miehet samalla tulivat uudelleen korostaneeksi naisille tunteidensa syvyyttä.

\title{
EPÄVIRALLINEN KIHLAUS VAHVISTAA SUHDETTA
}

Seurustelussa ei ollut kyse pelkästään tapailemisesta ja yhdessä vietetystä ajasta. Kahta tapausta lukuun ottamatta tarkasteltavat pariskunnat olivat jo seurustelun varhaisessa vaiheessa suunnitelleet avioliittoa tai ehtineet jopa kihloihin. Seurustelun tässä vaiheessa vähintäänkin haaveiltiin avioliitosta ja jopa harkittiin sitä vakaasti. Esimerkiksi itsellinen Abel oli kihlautunut itsellinen Siviä Emanuelintyttären kanssa ja antanut tälle kihloiksi kultasormuksen, kaksi huivia ja villaröijyn. Siviän edustaja myönsi heidän pitäneen "pieniä lempivehkeitä". (JyMA Keuruun Tk 7.4.1891, § 197.)

Tutkimuskirjallisuudessa on korostettu, että käytännön avioitumisprosessi oli vielä 1800-luvun lopun maaseudulla tarkkojen sääntöjen normittamaa ja ulkopuolisten ohjaamaa. Varsinaista kosintaa valmisteltaessa vanhempien, puhemiehen ${ }^{4}$ tai naimisiin aikovan miehen tuli ensin tiedustella asiaa. Tämän jälkeen kosintavierailulla esitettiin naimatarjous morsiamelle ja tämän naittajalle. Käytännöt ja muodot saattoivat vaihdella suuresti.

\footnotetext{
4 Puhemiesjärjestelmä on ollut Suomessa yleinen ja kaikissa maalaisväestön yhteiskuntaryhmissä vallitseva puolisonvalinnan epävirallinen järjestelmä. Puhemiehet etsivät puolisoehdokkaita ja heidät löydettyään olivat välittäjinä avioliiton solmimiseen liittyvissä asioissa, esimerkiksi kosinnassa, kihlauksessa ja kuulutuskirjojen hakemisessa. Yleensä puhemies oli aloitteellinen, mutta teki työtään myös vanhempien pyynnöstä. Mitä arvossa pidetympi puhemies yhteisössään oli, sitä arvokkaampana avioliittosuunnitelmaa pidettiin. Toisinaan naisesta kiinnostunut mies valtuutti itse puhemiehen asialleen. Puhemiehen käyttö ei ollut välttämätöntä. Sulhasehdokas ja hänen vanhempansa saattoivat kosimispuuhissaan toimia itsenäisesti morsianehdokkaan ja hänen vanhempiensa suuntaan. 1900luvun puolella puolison etsiminen ja valintaprosessi siirtyi nuorten omiin käsiin puhemiesinstituution kustannuksella. (Sarmela 1969, 64-68, 86-94, 168-172, 189, 208, 232233, 247, 249, 260, map 14: Proposal by Spokesman; Heikinmäki 1981, 50-52, 66-68, 70, 73-81, 86-94.) Puhemiehet olivat käytännössä miespuolisia, mutta naisilla oli oma vastaava roolinsa avioliittojen luonnissa. Ns. kontitsemista, "kontin kantamista" harjoittivat naispuoliset, naimattomat alemman sosiaaliryhmän edustajat: he kiersivät laajalla alueella kotitaloudesta toiseen välittäen nuorille miehille ja naisille juorujen muodossa tietoa mahdollisista puolisoehdokkaista. (Esim. Stark-Arola 1998, 108-111, 253.)
} 
Pasi Saarimäki: Nuorten miesten kirjeitse ohjailemat seurustelusuhteet 1800-luvun lopun 13 sisäsuomalaisella maaseudulla

[http://www.elore.fi/arkisto/2_14/saarimaki.pdf]

(Sarmela 1969, 86-91; Heikinmäki 1981, 65-86; Makkonen 2002, 165173.)

Kansanperinteen kosinta- ja viettelyrunot sekä mieronvirret ja joiut tarjoavat vivahteikkaan kuvan puolisonvalinnan normeista ja tavoista. Esimerkiksi maineeltaan kyseenalaisille kosijoille annettiin pakit, mutta rakkauden kohteena oleva ja hyvävarainen sulhanen oli suosittu. Kosinnan yleisyys runojen juonimallina kertoo siitä, että avioliittosopimusta pidettiin maaseutuyhteisöissä tärkeänä. Mieronvirsien ja joikujen perusteella oli mahdollista arvioida, ketkä partneriehdokkaista olisivat sopivia ja ketkä sopimattomia puolisoiksi. (Knuuttila \& Kupiainen 2003, 157-159; Tarkka 2005, 201-214, 235-247.) Tarkastelemissani suhteissa nuorten seurustelu ja kahdenkeskiset sopimukset olivat korvanneet varsinaisen virallisen kosintatilaisuuden. Käytäntö yleistyi 1900-luvulle tultaessa, jolloin nuorten keskinäisiä tulevaisuuden suunnitelmia alettiin pitää avioliittojen ensisijaisena perustana. (Heikinmäki 1981, 65, 86-94; Raitasalo 2004, 124-125.)

Seuraava vaihe, kihlaus, oli vapaamuotoinen ja vapaaehtoisuuteen perustuva kahden ihmisen oikeudellisesti pitävä sopimus. ${ }^{5}$ Kuten kosintaan, myös kihlaukseen liittyi monenlaisia paikallisia tapoja ja sääntöjä tapahtuman sisällöstä. Kihlajaistilaisuus saattoi olla jäyhän toteava mutta toisinaan varsinainen perhejuhla. (Sarmela 1969, 91-94; Heikinmäki 1981, 129-151.) Tutkimieni pariskuntien kihlaukset sen sijaan olivat kahdenkeskisiä. Torpanpoika Abraham oli halunnut mennä naimisiin itsellisentytär Wilhelminan kanssa, vaikka tämä oli raskaana toiselle miehelle. Molempien vanhemmat olivat antaneet nuorten keskinäiselle kihlaukselle suostumuksen ja siunauksen. (Keuruun Vk 20.2.1897, §1; Tk 20.3.1897, § 136.)

Kaarle Kaarlenpoika oli puolestaan saanut aviolupauksen avulla Wilhelmina Hermannintyttären purkamaan aiemman kihlauksensa. Kaarlen vanhemmat olivat kuulleet pariskunnalla olleen "naimisenhankkeita" mutta pelkäsivät Kaarlen "narraavan kantajaa". Toivoessaan "että asiasta tulisi jokin tolkku eikä kantaja joutuisi petetyksi", he olivat pyytäneet talollinen Oskar Kaarlenpojan puhemieheksi välittämään avioliittoneuvotteluja. Kaikki oli ollutkin valmiina kihlakuulutusten hakemista varten, sillä kyläläiset tiesivät heidän olleen kihloissa keskenään ja Kaarlen antaneen

\footnotetext{
5 Voimassa olleen Ruotsin valtakunnanlain 1734 naimakaaren mukaan oikeudellisesti pätevään kihlaukseen tarvittiin naittajan suostumus, jos nainen oli alle 21-vuotias. Naittaja oli ensisijaisesti tyttären isä. Lisäksi kihlaustapahtumaa olisi periaatteessa pitänyt naittajan lisäksi olla todistamassa kaksi todistajaa sekä miehen että naisen puolelta. (RVL 1734 (1909), Naimiskaari, 1. luku, § 1-5, 3. luku, § 1-3; Kuninkaallinen asetus 14.1.1726; Keisarillinen asetus 31.11.1864, § 1-2; Håkanson 1999, 26-27, 129-142; Hemmer 1967, 4, 12-14.)
} 
Pasi Saarimäki: Nuorten miesten kirjeitse ohjailemat seurustelusuhteet 1800-luvun lopun 14 sisäsuomalaisella maaseudulla

[http://www.elore.fi/arkisto/2_14/saarimaki.pdf]

Wilhelminalle sormuksen. (JyMA Keuruun Tk 19.2.1892, § 196.) Pariskuntien alustavat, aviolupauksin tai kihlauksin varmennetut päätökset avioliitosta olivat lähes aina kahdenkeskisiä. Kihlaukset eivät siis missään vaiheessa muuttuneet virallisiksi, ja tämän osapuolet myös tiesivät. Esimerkiksi itsellisen Siviä Emanuelintyttären edustaja kielsi Siviän ja Abelin koskaan "oikeissa kihloissa sekä vastaajan saaneen kantajalta mitään muuta kuin tuon sormuksen". (JyMA keuruun Tk 7.4.1891, § 197.)

Ainoastaan yhdessä kirjeessä käsiteltiin kihlauksen kirkollista virallistamista eli avioliittokuulutusten hakemista. Renki Emil Kustaanpoika oli kirjoituttanut keväällä 1894 puhemiehellään torppari Nehemias Abrahaminpojalla kosiokirjeen Johanna Abrahamintyttärelle. Kirjeessä sovittiin kihlauskuulutuksen hakemisesta:

[...] että hän tullee pääsiäis lauvantaina sinne sinun tykös ja sitten käyvään vähä etenpänä jos ei millään erinomasta estettä tule ja muu ei estä kuin taita ja sairaus. (JyMA Keuruun Sk 29.10.1895, § 248, liite kopare.)

Vuoden 1869 kirkkolain mukaan kihlattujen tuli ilmoittaa asiasta kirkkoherralle. Käytännössä pariskunnan tuli matkata pappilaan kuulutuskirjaa hakemaan, minkä jälkeen avioesteiden selvittämiseksi tuleva avioliitto kuulutettiin kirkossa kolmena sunnuntaina. ${ }^{6}$ Kuulutusten myötä kihlaus tuli julkiseksi asiaksi paikallisyhteisön keskuudessa ja kirkon silmissä viralliseksi, mahdollisimman pikaista vihkimistä odottavaksi liitoksi. Jos kihlapari halusi kuulutusten jälkeen purkaa päätöksensä avioliitosta, heidän tuli hakea kihlaeroa maallisilta tai kirkollisilta viranomaisilta. ${ }^{7}$

\section{KIHLAUS NAISTEN TURVA NAIMATTOMUUTTA JA RASKAUTTA VASTAAN}

Olen edellä tarkastellut sitä, miten miehet kirjeiden välityksellä kertoivat romanttisista tunteistaan ja yrittivät sopia tapaamisista. Miesten lähettämät kirjeet sisältöineen vaikuttivat osaltaan siihen, että suurin osa seurustelusuhteista edistyi jo kihlautumisen asteelle. Avioliitto oli periaatteessa jo hyvin lähellä toteutumistaan.

\footnotetext{
6 RVL 1734 (1909), Naimiskaari: 7. luku, § 2; KL 1869: 9. luku (Vihkimisestä avioliittoon), $\S$ 72-74; Hemmer 1967, 14; Heikinmäki 1981, 158-161, 167-170; Losman 1982, 295; Håkanson 1999, 27, 129-130, 142-146.

7 Kihlaeroa voitiin hakea suoraan tuomiokapitulilta, jos molemmat osapuolet halusivat purkaa kihlauksen, ja vakuuttivat hakemuksessaan, etteivät he olleet seksuaalisessa kanssakäymisessä. Erityistä syytä purkamiseen ei tarvittu. Jos mies ja nainen olivat erimielisiä kihlauksen jatkamisesta, kihlaero tuli viedä paikalliseen oikeuteen, joka myönsi harkintansa mukaan eron. Lisäksi kihlaus voitiin katsoa jälkikäteen mitättömäksi useasta eri syystä. (RVL 1734 (1909), Naimiskaari: 4.luku, § 1-8; Kuninkaallinen kirje 11.11.1747; Hemmer 1967, 14; Taussi Sjöberg 1988, 54-57, 124-130; Håkanson 1999, 134-138.) Erosääntöjen käytännön soveltamisesta esim. Losman 1982, 295-296, 298301, 306-308; Saarimäki 2014, 109-113.
} 
Pasi Saarimäki: Nuorten miesten kirjeitse ohjailemat seurustelusuhteet 1800-luvun lopun 15 sisäsuomalaisella maaseudulla

[http://www.elore.fi/arkisto/2_14/saarimaki.pdf]

Kirjeet ja miesten kihlausehdotukset saivat naisilta myönteistä vastakaikua. Mistä syystä miesten kirjeissään esittämät emotiivit ja ajatukset kihlautumisesta olivat naisille mieleen? Miksi he halusivat mahdollisimman varhaisessa vaiheessa uskoa miesten vakuutteluja avioliitosta? Merkittävä syy oli pelko jäädä naimattomaksi, joka on tullut esiin useissa tutkimuksissa. Maaseutuyhteisössä vallitsi kulttuurinen oletus siitä, että ihmisten tuli mennä naimisiin, joten nuorten naisten tärkeimpänä tulevaisuuden tavoitteena oli avioituminen. (Håkanson 1999, 24; Nieminen 1993, 7; Vakimo $2001,141$.$) Ihanteellisen naimaiän ohittaneisiin voitiin kohdistaa$ pilkkaa, tai heitä voitiin nimittää halventavasti vanhoiksi pojiksi tai vanhoiksi piioiksi (Heikinmäki 1981, 42-43; Niekka \& Petrelius 1993, 9, 13; Raitasalo 2004, 71, 85, 125, 127-128). Perillisten puuttuessa avioitumattomien mielissä siinsi lisäksi pelko vanhuuden taloudellisesta epävarmuudesta.

Kansanperinteessä korostui naimattomien naisten kielteinen kohtalo. Vanhapiikoja koskevissa kaskuissa pohdittiin kyläyhteisön avioliiton ulkopuolelle jääneen naisen suhdetta normaaliin naiseuteen ja sukupuolisuuteen. Nimitykset, kuten vanhapiika, ikäneito tai vanhatyttö, olivat vahvasti normittavia, ja niillä pyrittiin ohjaamaan naisen elämänkulkua yhteisössä sopivaksi katsottuun suuntaan. (Löfström 1999, 94; Vakimo 2001, 135-136, 141, 157; Niekka \& Petrelius 1993, 2, 4, 13.) Avioliiton solmimalla ihminen varmisti muiden silmissä täysivaltaisen jäsenyyden yhteisössä (Gaunt 1996, 14). Vanhapiika-termiä saatettiin käyttää varoittavana esimerkkinä muistuttamassa tytölle esiaviollisten suhteiden vaarallisuudesta. Aikuisen naisen sallitun seksuaalisuuden paikka oli avioliitossa. (Löfström 1999, 94-95; Vakimo 2001, 141-142, 153-158.) Avioliiton mahdollisuuksia, naimaonnea, pyrittiin maaseutuyhteisössä lisäämään seksuaaliväritteisellä magialla. Lemmenostoloitsujen uskottiin herättävän miesten kiinnostuksen naista kohtaan. Henkilökohtaista seksuaalista viehätysvoimaa, lempeä, voitiin lisätä esimerkiksi kylvetysrituaalien avulla. (Stark-Arola 1998, 90-92, 132-138, 211-223; Piela 1990, 214-223; Paasio (toim.) 2004, 11-30.)

Naimattomaksi jääminen ei ollut ainoa pelko, joka sai naiset turvautumaan miesten lupauksiin. Maaseudun seurustelusuhteet muuttuivat nopeasti seksuaalisiksi, jolloin nainen saattoi tulla raskaaksi. Kaikissa tarkasteltavissa tapauksissa osapuolet olivat olleet suhteen aikana ainakin muutaman kerran sukupuoliyhteydessä. Esimerkiksi renki Emil Kustaanpoika oli piika Johanna Abrahamintyttären mukaan syksyllä 1894 viekoitellut hänet "naimisen lupauksella [...] kanssansa lihalliseen yhteyteen." Johannan makuukamarissa tapahtuneen "lihallisen yhteyden" oli havainnut Johannan työtoveri, piika Wilhelmiina Taavetintytär. (JyMA Keuruun Sk 29.10.1895, § 248.) Talollisenpoika Viktor Obadiaksenpoika 
Pasi Saarimäki: Nuorten miesten kirjeitse ohjailemat seurustelusuhteet 1800-luvun lopun 16 sisäsuomalaisella maaseudulla

[http://www.elore.fi/arkisto/2_14/saarimaki.pdf]

oli aloittanut seksuaalisuhteen suntiontytär Hulda Marian kanssa toukokuussa 1897, eikä Viktor asiaa erityisemmin salannut. Hän oli kehuskellut ulkopuolisille olleensa "lihantöissä", ja tunnustanut kysyttäessä saaneensa "naimista". (JyMA Keuruun Tk 16.2.1899, § 149.) Tullitarkastaja Oskar oli puolestaan tehtaantyöntekijän Gustavan mukaan kihlannut tämän morsiamekseen ja "sellaisena maanneen". (JyMA Keuruun Sk 14.9.1889, § 141.)

Yhteisön seksuaalinormit määrittelevät sen, kuinka sallittua esiaviollinen seksi on. Luokkakohtaiset ja sukupuolittuneet koodistot ovat aina vaikuttaneet yksilöiden päätökseen seksin harrastamisesta, jolloin yhdyntä on tietyissä tilanteissa ollut looginen, hyväksytty ja jopa järkevä ratkaisu. (Szreter \& Fisher 2010, 115-116.) 1800-luvun lopulla naimattomien ihmisten seksuaalielämä oli tietyissä puitteissa sallittua. Esiaviollista seksuaalielämää ei periaatteessa yhteisön normien tasolla hyväksytty salavuoteus, eli naimattomien ihmisten seksuaalinen kanssakäyminen, oli lisäksi oikeudellisestikin rangaistavaa ${ }^{8}$ - mutta sitä siedettiin ja katsottiin läpi sormien, jos pariskuntien avioliittoaikeet olivat tiedossa. (Saarimäki 2010, 47-48.) Esiaviolliset suhteet olivat maaseutuyhteisössä yleisiä, ja olennainen osa avioliittoon johtavaa prosessia (Nieminen 1951, 74-77, 79, 88; Kälvemark 1983, 20-21; Håkanson 1999, 150, 164, 168, 175).

Erityisesti kihlaus oli yhteisön hyväksymä lähtöpiste seksuaalielämän aloittamiselle, sillä se oli varhaisempina aikoina ollut vihkimistä merkittävämpi avioliiton muodostanut toimenpide. Vasta vuoden 1734 Ruotsin valtakunnanlaissa kirkollinen vihkiminen tuli pakolliseksi ja samalla tärkeimmäksi osaksi avioliiton solmimista. (Gaunt 1996, 66-70; Taussi Sjöberg 1988, 56-57.) Kansan keskuudessa kihlaus kuitenkin säilytti merkittävyytensä. Sukupuolielämä ja yhdessä asuminen voitiin aloittaa, koska kihlausta pidettiin varmennuksena tulevasta avioliitosta. (Nieminen 1951, 74-77, 79; Frykman 1977, 183-184; Håkanson 1999, 138, 168, 171.) Yhteisten öiden viettäminen tuli sallituksi erityisesti kihlakuulutusten esittämisen jälkeen (Heikinmäki 1981, 177), koska tällöin avioliitto oli oikeudellisessa mielessä enää vihkimistä vaille valmis.

Seksin harjoittamisesta saattoi kuitenkin tulla raskaaksi, ja naisten pelkoa lisäsi se, että tunnetut ehkäisykeinot olivat 1800-luvun lopulla epävarmoja tai tehottomia. Toimivimmasta päästä olivat keskeytetty yhdyntä, imettäminen ja seksin välttäminen tiettyyn kuukautiskierron aikaan. Muita

8 Uuden, vuoden 1889 rikoslain mukaan salavuoteudesta tuli saada sakot, miehen korkeintaan 40 markkaa ja naisen enintään 20 markkaa. Teon toistuvuudella ei ollut enää vaikutusta sakkojen määriin. (Rikoslaki 1889, 20. luku, § 9.) 1800-luvun lopulla oikeustuomiot salavuoteudesta olivat Suomessa käytännössä jo hyvin harvinaisia. Salavuoteus poistettiin rikoslainsäädännöstä vuonna 1926. (Saarimäki 2010, 192; Anttila 1956, 2223.)

Elore (ISSN 1456-3010), vol. 21 - 2/2014. Julkaisija: Suomen Kansantietouden Tutkijain Seura ry. 
Pasi Saarimäki: Nuorten miesten kirjeitse ohjailemat seurustelusuhteet 1800-luvun lopun 17 sisäsuomalaisella maaseudulla

[http://www.elore.fi/arkisto/2_14/saarimaki.pdf]

keinoja olivat luonnonlääkkeet - esimerkiksi katajanmarjavesi - tai emätinhuuhtelut erilaisilla kemikaaleilla. (Esim. Jauhiainen 1990, 136, loppuviite 5; Helsti 2000, 224-226; Ritamies 2006, 83-84, 98-101.) Uskomusten mukaan myös esimerkiksi taikojen tekeminen ennen yhdyntää, hengityksen pidättäminen yhdynnän aikana tai tietyt yhdyntäasennot ehkäisivät raskautta (Jauhiainen 1990, 136, loppuviite 5; Helsti 2000, 224-225; Paasio (toim.) 2004, 168-180; Stark-Arola 1998, 47, 142144).

Ehkäisyä pidettiin 1800-luvun suomalaisessa yhteiskunnassa paheksuttavana (Ritamies 2006, 80), joten sen harjoittamista voitiin aristella. Uskomustarinoiden eetos oli ehkäisyä tai raskauden keskeyttämistä vastaan: tarinoissa esimerkiksi kuvattiin, kuinka naiset kuolemansa hetkellä näkivät syntymättömät lapsensa tai joutuivat synnyttämään ne. Ehkäisy voitiin jopa rinnastaa lapsenmurhaan. Maaseutuyhteisöissä kerrottiin lapsenmurhatarinoita, joissa lapset kummittelivat äideilleen. Molemmat tarinatyypit edustivat symbolista viestintää, jolla lausuttiin julki yhteisön normeja ja säädeltiin sen jäsenten elämää. (Jauhiainen 1990, 128-129; Nousiainen 1990, 162-165.)

Aviolupausten tai kihlautumisen myötä naiset saivat ainakin suullisen varmuuden siitä, että miehet pysyisivät heidän rinnallaan raskauden sattuessa, ja olisivat tosissaan tulevan avioliiton suhteen. Sanallisilla lupauksilla ja kosinnan kulttuuristen muotojen toistamisella miehet pystyivät korostamaan naisille avioaikeiden vakavuutta. Tällä tavoin heidät vakuutettiin tulevasta avioliitosta. (Telste 1999, 84-91.) Seurustelu- ja kihlausaikojen tuli kuitenkin olla mahdollisimman lyhyet. Jos kihlausajat venyivät, suhteissa oli merkittäviä ongelmia, ja ne eivät enää kehittyneet kohti avioliittoa (Frost 1995, 84-88, 101; Saarimäki 2010, 134-139, 184-193). Aineistoni ihmiset eivät kuitenkaan päätyneet avioliittoon. Suhteet alkoivat sitä vastoin säröytyä naisten tultua raskaaksi ja ilmoitettua asiasta miehille.

\section{RASKAUS JA SYNTYMÄ SUHTEIDEN KÄÄNNEKOHTANA}

1800-Iuvun seurustelusuhteissa raskaus nopeutti avioitumisprosessia, sillä miehet ja naiset eivät halunneet lapsensa syntyvän aviottomana. Paikallisyhteisö hyväksyi esiaviolliset raskaudet, kunhan pariskunnat olivat menossa lähitulevaisuudessa naimisiin. (Lukkarinen 1933, 15-16; Nieminen 1951, 87-88; Kälvemark 1977, 181-182, 184, 189, 195.) Tällaiset raskaudet olivat maaseudulla verrattain yleisiä. (Nieminen 1951, 74-77; Håkanson 1999, 151-153; Saarimäki 2010, 54-55.) 
Pasi Saarimäki: Nuorten miesten kirjeitse ohjailemat seurustelusuhteet 1800-luvun lopun 18 sisäsuomalaisella maaseudulla

[http://www.elore.fi/arkisto/2_14/saarimaki.pdf]

Raskaus ei kuitenkaan aineistoni ihmisten kohdalla vauhdittanut avioitumistietä, vaan se oli käännekohta suhteen kehityksessä. Miehet ja naiset joutuivat aivan uudenlaisen tilanteen eteen. Raskauden jälkeisissä kirjeissä avioliitto oli yhä aiheena, mutta kirjeistä välittyy epävarmuus siitä, miten pitäisi toimia. Tutkimissani kirjeissä miesten pyrkimykset ohjailla suhteita muuttuivat. He eivät enää yrittäneet kirjeillään syventää seurustelusuhdetta, vaan reagoivat muuttuneeseen tilanteeseen. Käytettävistä kirjeistä ei ole löydettävissä yhtä reagointimallia, vaan miesten näkemysten voi sanoa vaihdelleen monenlaisten tunnetilojen välillä. Kirjeiden sisällön perusteella voi tulkita, että ainakin joissain tapauksissa naiset olivat lähettäneet miehille kirjeitä, joissa he toivat julki epäilyksensä siitä, kantaisiko mies vastuunsa yhteisestä lapsesta. Miehet puolestaan pyrkivät rauhoittavan luonteisilla kirjeillä reagoimaan naisten kirjeisiin ja vakuuttamaan sitä, että heillä oli vielä tunteita naisia kohtaan.

Esimerkiksi kesällä 1884 tullitarkastaja Oskar kirjoitti raskaaksi tulleelle morsiamelleen tehtaantyöntekijä Gustavalle tunteikkaita, Iohduttavia sanoja.

Viimeisestä kirjeestäsi huomaan sinun olevan epäilyksessä, vaan jos vähänkin pidät minusta niin elä epäile mitään ja jos niinkin tekisit, niin älä millään lailla näytä sitä. Sinä tiedät hyvin mitä olen kärsinyt ja tiedät myöskin etten ole voinut tehdä mitään parantaaksesi tilaasi.

Samalla Oskar kertoi tunteistaan ja välimatkan aiheuttamasta ikävästä.

Niin kuin näet olen jo täällä Lammilla ja odotan kärsimättömyydellä päästä täältä pois, saadakseni sitten päästä katsomaan lemmittyäni ja täyttämään pyyntösi [...] Myöskin sen tiedät kuinka äärettömästi pidän sinusta, enemmän kuin itsestäni ja kaikesta muusta tässä maailmassa [...] Ei mikään niin rasita täällä kuin aate etten voi nähdä omaani joka yöt ja päivät on mielessäni. Ei hetkeäkään, jolloin olisin unhotta sinua rakkaani. Älä nyt ikävöitse, vaan ole kärsivällinen kyllä kaikki muuttuu parempaan. (JyMA Keuruun Sk 14.9.1889, § 141, liite a.)

Lapsen syntymän jälkeen Oskar jatkoi kirjoitteluaan. Hän kysyi lapsen vointia ja vakuutteli edelleen tunteidensa aitoutta.

Kuinka pienen Irman kanssa on, onko se terve, sano sille sydämelliset terveiset ja anna isän puolesta sille suukkonen. [...] Minä olen tullut kipeäksi ehkä ikävästä ja surusta vaan mikä on ollut tehtävä kun ei missään ole löytynyt ystävää joka olisi voinut lohduttaa mieltäni [...] Sinä olet nyt yksin täytynyt toimittaa kaikki, minä olen siitä hyvin kiitollinen ja pidän sen kyllä muistissa. (JyMA Keuruun Sk 14.9.1889, § 141, liite Hämeenlinna 15/1 1885.)

Miehet kirjoittivat toisinaan kirjeissään lapsen syntyperästä, silla aviottomana syntyminen oli yhteisön normien vastaista. Oskar kysyi kirjeessään 
Pasi Saarimäki: Nuorten miesten kirjeitse ohjailemat seurustelusuhteet 1800-luvun lopun 19 sisäsuomalaisella maaseudulla

[http://www.elore.fi/arkisto/2_14/saarimaki.pdf]

"Mitä pappi sano kuin Irma vietiin ristille kyllä kai paperit olivat täydelliset lullani. Pidä nyt sitä hyvin ettei se kylmety ja itseäsi myös". Oskaria oli huolestuttanut tulevaisuus jo raskauden aikana, sillä hän oli vienyt kevättalvella 1884 Gustavan pitäjästä pois, sillä ei puheiden perusteella ollut halunnut jättää "[...] sitä Mänttään pilkattavaksi huoraksi ynnä muuksi". (JyMA Keuruun Sk 14.9.1889, § 141, liite Hämeenlinna 15/1 1885.)

Oskarin käyttämä huora-ilmauksen merkityskenttä oli 1800-luvun lopulla laaja. Leea Virtasen keräämässä nimittely-aineistossa 1900-luvun alkupuoliskolla syntyneet vastaajat ymmärsivät yhdeksi huora-termin määritelmäksi aviottoman lapsen synnyttäneen naisen. Myös Lotte Tarkka paikantaa vienankarjalaisen "Natalian nauru" -runon huoran isättömän lapsen äidiksi. Aviottoman lapsen synnyttäminen oli häpeällinen ja yhteisön tuomitsema tapahtuma, ja huoraksi tulemista, "huora-sikiön" synnyttämistä haluttiin välttää. Huora-termin käytöllä oli maaseutuyhteisöissä moraalinen tehtävä: pelottelun keinoin tytöille opetettiin soveliaan käyttäytymisen rajat. (Virtanen 1990, 141-142, 145, 147-150, 157; Tarkka 2005, 222-223, 230-232; ks. Löfström 1999, 155-156.) Ruotsalaisen etnologi Jonas Frykmanin mukaan huoraksi kategorisoidun naisen nähtiin jopa omaavan erityistä voimaa. Heidän pelättiin pahalla silmällä, pahoilla sanoilla tai kosketuksella vahingoittavan ja sairastuttavan erityisesti syntymättömiä lapsia ja imeväisikäisiä. (Frykman 1977, 26-74; naisten omaamasta voimasta, "naisen väestä", esim. Apo 1998.)

Todellisuudessa suhtautuminen aviottomiin äiteihin saattoi tilanteesta ja persoonasta riippuen vaihdella siedetyn ja paheksutun välillä. Naisten myöhempiä elämänvaiheita ei voi asettaa yhteen muottiin: sosiaalinen ja taloudellinen asema vaihteli yksilöiden välillä. (Kälvemark 1978, 89-93; Virtanen 1990, 147-150; Håkanson 1999, 78-82, 219-221; Miettinen 2012, 181-185, 252-253, 268-269.) Yhteisön normit aviottomaan syntymään liittyen olivat kuitenkin selkeän kielteiset. Tämä johtui siitä, että aviottomalla lapsella ei ollut avioliiton antamaa selkeää perintöoikeutta ja sen tuomaa asemaa yhteisössä. Avioliitossa syntynyt lapsi sen sijaan asettui heti oikealle ja lailliselle paikalleen maataviljelevässä yhteisössä, ja hänen sukunsa sekä holhoojansa olivat tiedossa. (Esim. Miettinen 2012, 90, 167, 267.) Kirjeissä näkyykin, että miehet olivat huolissaan yhteisön jäsenten suhtautumisesta heidän siittämäänsä lapseen ja samalla heihin itseensä.

Esimerkiksi talollisenpoika Viktor Obadiaksenpoika kuvasi morsiamensa jo viidennellä kuukaudella ollutta raskautta "ikäväksi tilaksi ja ikäväksi asemaksi". Kirjeessään Viktor nuhteli Hulda Mariaa asian julkiseksi tekemisestä. Hän kirjoitti Hulda Marian tehneen 
Pasi Saarimäki: Nuorten miesten kirjeitse ohjailemat seurustelusuhteet 1800-luvun lopun 20 sisäsuomalaisella maaseudulla

[http://www.elore.fi/arkisto/2_14/saarimaki.pdf]

\begin{abstract}
oikeen tuhmasti Kuin sen ilmoitit Kaikkillen olisithan voinut suoranaisesti piirrellä minulle asijasta siis sehän on yleinen huhu mänttässä ja josta kuulen joka päivä. Vaikka kyllä minä Kärsin ja kärsiinhän tänne ihminen on luotukin.
\end{abstract}

Omasta osuudestaan Viktor totesi, että

\begin{abstract}
tämä on niin pimeä paikka että mitä jos minä olen joka olen ryöstänyt rauhan sinun rinnastas niin minulla on aina omatunto vaikkapa Ei koskaan olis muutakaan miehuutta. (JyMA Keuruun Tk 16.2.1899, § 149, liite Mänttästä 18 10/11 97.)
\end{abstract}

Kirjeen perusteella Viktoria häiritsi erityisesti, että tieto raskaudesta ja hänen isyydestään oli levinnyt paikallisyhteisössä, muuttunut julkiseksi asiaksi. Viktor pelkäsi oman maineensa heikkenemistä yhteisön sisällä. Jos 1800-luvun lopun maaseudulla aviottoman lapsen isä oli yleisessä tiedossa, yhteisö edellytti tämän hoitavan ongelman joko avioitumalla lapsen äidin kanssa tai maksamalla lapsenelatusta. Jos lapsen isä ei täyttänyt näitä yhteisöllisiin seksuaalinormeihin pohjautuvia vaatimuksia, hänen miehen maineensa, mieheytensä, oli vaarassa. (Kotilainen \& Saarimäki 2013.)

Kirje paljastaa Viktorin ymmärtäneen riskin maineensa huononemisesta yhteisössä, kun hänen isyytensä oli tullut julkiseksi. Hän kuitenkin koetti omaa asemaansa varjellakseen syyttää Huldaa asian paljastamisesta. Tällä tavalla Viktor yritti reagoida seurustelun näkyvään seuraukseen, raskauteen.

\title{
TUNTEIDEN VIILENEMINEN, HYLKÄÄMINEN JA MUSTASUKKAISUUS
}

Miksi seurustelevat parit eivät sitten menneet naimisiin pitkälle edenneestä seurustelusuhteesta ja raskaudesta huolimatta? Kyse on voinut olla siitä, että tunteet ja rakkaus jossain vaiheessa viilenivät. Esimerkiksi ruotsalaisista 1600-luvun kihlaerotapauksista, joita voi verrata suomalaisiin, käy selville, että rakkauden puuttumista pidettiin riittävänä perusteena suhteen purkamiselle (Lennartsson 1999, 171-181, 185-186). Kaksisataa vuotta myöhemmin tunnesyyt olivat yleisimmät perusteet hakea tuomiokapitulista kihlaeroa. Kiintymys tai rakkaus oli kadonnut molemmilta tai toiselta osapuolelta, ja kielteiset tunteet tulleet tilalle. (Taussi Sjöberg 1988, 121, 123.) Asia ilmaistiin 1800-luvun lopun käräjäaineistossa välien tai rakkauden kylmenemisenä. Itsellinen Siviä Emanuelintyttären asiamies kertoi oikeudessa Abelin antaneen tälle sormuksen, "jonka vastaaja sitten asiallisten välin kylmettyä oli jättänyt takaisin kantajalle". (JyMA Keuruun Tk 7.4.1891, § 197.) Asiasta voitiin oikeudessa puhua myös ivalliseen sävyyn. Torpantytär Hilda Maria Hermannintyttären mukaan talonpoika Aleksi Augustinpoika oli naima-aikeitaan todistaakseen 
Pasi Saarimäki: Nuorten miesten kirjeitse ohjailemat seurustelusuhteet 1800-luvun lopun 21 sisäsuomalaisella maaseudulla

[http://www.elore.fi/arkisto/2_14/saarimaki.pdf]

antanut kultaisen kihlasormuksen, mutta oli "vastaajan rakkaus nyt kylmennyt niin ettei hän enää ota huoliakseen kantajasta enempi kuin lapsestaankaan". (JyMA Keuruun Tk 21.2.1895, § 213.)

Mikäli miehet eivät alun perinkään olleet, puheistaan huolimatta, tosissaan ja olisivat olleet kiinnostuneita ensisijaisesti seksisuhteesta, he olisivat käyttäneet hyväkseen avioliittoa ennakoivan seurustelun muotoja ja hylänneet naiset raskaaksi tulemisen jälkeen (Frost 1995, 104-105; Saarimäki 2010, 71). Lapsenelatustapausten kannekirjoissa ja alkupuheenvuoroissa naiset korostivat juuri aviolupausten pettämistä ja hylkäämistä. Esimerkiksi torpantytär Amalia Samuelintytär kirjoitti:

Tukkiasioitsija [...] joka teeskennellen olevansa minun todellinen rakastajani, on kihlannut minun avioliittoon ja se nojalla houkutellut minun kanssansa salavuoteuteen. [...] ei ole kauppaansa perännyt, josta huomaan, että olen tullut suuresti petetyksi. (JyMA Keuruun Tk 12.4.1883, § 233.)

Viimeistään naisen tultua raskaaksi miehet joutuivat miettimään tosissaan aiempia puheitaan. Ehkä aviolupaukset oli annettu siinä vaiheessa, kun niiden toteuttamista ei ollut tarvinnut ajatella (ks. myös Frost 1995, 102). Miehet saattoivat myös huomata, että taloudellisia mahdollisuuksia avioliittoon ei löytynyt. Esimerkiksi tilattomalla ja köyhällä miehellä ei välttämättä ollut edellytyksiä perustaa omaa perhettä ja kotitaloutta. (Esim. Kälvemark 1983, 23-25; Saarimäki 2010, 73-74; Håkanson 1999, 28-29, 47-58, 221.) Elämä köyhänä itsellisperheenä toisten nurkissa ei houkutellut.

Toisinaan mahdolliset suhteet kolmanteen osapuoleen pahensivat tilannetta. Neljässä tapauksessa miehet epäilivät toisen miehen tulleen kilpailemaan naisen suosiosta ja pahimmassa tapauksessa olleen jopa vastuullisia raskaudesta. Kyse oli tällöin mustasukkaisuudesta. Torpparinpoika Edvin Samuelinpoika oli useammalle ulkopuoliselle tunnustanut seksuaalisuhteen itsellinen Edla Fredrikintyttäreen mutta kielsi "olevansa kyllä vikapää ihmiseen, mutta ei lapseen". Oikeudelle antamassaan kirjeessä Edvin korosti, että Edlalla
tosijaankin kuuluu talvenakin niin monta kosijanta ettei hän it- sekkään voi ihan tarkkaan tietää kennen pussista simmeen olis pudonnut [...] kuinka tällainen ihmiinen joka näin monen kanssa yhtyyttä pitää tietää itsekkään kuka hänen lapsensa isä on. (JyMA Keuruun Sk 29.10.1896, § 266; Tk 18.3.1897, § 88, liite Tillistä; Sk 7.10.1897, § 28.)

Vatsanpolttotauti oli estänyt alun perin renki Emil Kustaanpoikaa lähtemästä hakemaan kihlauskuulutuksia, mutta myöhemmin hän kertoi torppari Nehemiakselle jättävänsä "naimispuuhan sikseen, koska kantaja muka on raskaana muista miehistä". (JyMA Keuruun Sk 29.10.1895, § 248.) Miesten kirjoituksista voi lukea moraalisen närkästymisen. 
Pasi Saarimäki: Nuorten miesten kirjeitse ohjailemat seurustelusuhteet 1800-luvun lopun 22 sisäsuomalaisella maaseudulla

[http://www.elore.fi/arkisto/2_14/saarimaki.pdf]

Syyttämällä elatusoikeudenkäynneissä muita miehiä naisen raskaudesta he leimasivat myös naiset vähintäänkin epäsuorasti (Pohjola-Vilkuna 1995, 52-54). Seksuaaliset suhteet useiden eri miesten kanssa yhtä aikaa tai tällaisesta huonon maineen saaneet naiset joutuivat poikkeuksetta yhteisön paheksumiksi (Miettinen 2012, 133, 164-165). Samalla he leimautuivat huonoiksi naisiksi (Nieminen 1951, 88; Virtanen 1990, 147).

Miesten esittämiin väitteisiin on osaltaan suhtauduttava varauksella. Toisista miehistä ei välttämättä aina ollut todisteita, ja niillä yritettiin vain puolustautua isyyssyytöksiltä. Paikkakunnan yöstelyperinteen mukaisesti useammat miehet saattoivat käydä vierailuilla naisten luona. Tämä antoi miehille mahdollisuuden luetella oikeudessa toisten miesten nimiä. (Saarimäki 2006, 199-202.) Toisaalta toisten miesten syyttelyllä miehet yrittivät ratkaista käsillä olevan ongelman, raskauden ja lapsen vuoksi kriisiytyneen suhteen.

Kirjeissä kysyttiin usein toisista miehistä. Esimerkiksi talollisenpoika Viktor Obadiaksenpoika oli suhteen alkuvaiheessa arvellut toisen miehen olevan syynä siihen, ettei suntiontytär Hulda Maria ollut tullut sovittuun tapaamiseen:

mutta nyt täytyy heitää kaikki pois muistostani mitä meidän välillä on ollut ja varmaan sinulla on muita rakkahampia kun minä ja ehkä se on se satulamaakari ja onkin niin en tahdo olla koskaan enää Haittana sinullen siinä tapauksessa. Jää hyväksi ainaiseksi. (JyMA Keuruun Tk 16.2.1899, § 149, liite Mänttä 18 3/6 97 Kesäkuuta.)

Jatkosodan aikaisia rintamiesten kirjeitä tarkastelleen Erkka Pehkosen mukaan mustasukkaisuuteen liittyi kaksi perusmerkitystä. Ensimmäinen oli pelko toisen menettämisen mahdollisuudesta, ja toinen puolestaan kokemus luottamuksen pettämisestä, häpeästä ja loukatuksi tulemisesta. (Pehkonen 2013, 173-174.)

Huldan raskaaksi tulon jälkeen Viktor kirjoitti tälle katkeransävyisen kirjeen, jossa kyseenalaisti tulevan isyytensä. Viktori kysyi kirjeessään

onko sinulla puhdas oma tunto [...] kuules minkä tähden minä en ole uskonu että se olen juuri minä joka olen sinut viettänyt tähän ikävään asemaan.

Viktor odotti kiinnostuneena syntymän hetkeä, joka todistaisi, ettei hän voisi olla isä:

Muistanetthan ne hettket [...] eikä siis ole muuta aikaa kulunut. Näjes aika ne kaikki Toteksi näyttää minä en usko ennen ollenkaa. 
Pasi Saarimäki: Nuorten miesten kirjeitse ohjailemat seurustelusuhteet 1800-luvun lopun 23 sisäsuomalaisella maaseudulla

[http://www.elore.fi/arkisto/2_14/saarimaki.pdf]

Viktor oli lisäksi useammalle ulkopuoliselle ilmoittanut, että hän olisi todistettavasti isä vain, jos lapsi syntyisi helmikuussa. (JyMA Keuruun Tk 16.2.1899, § 149, liite Mänttästä 18 10/11 97.)

Miehet esittivät mustasukkaisia tiedusteluja toisista miehistä sekä seurustelun syventämisvaiheessa että raskauden jälkeen lähettämissään kirjeissä. Suhteiden alkuvaiheissa niiden tarkoituksena oli tiedustella muista kosijoista ja yrittää torjua heitä. Raskauden jälkeen mustasukkaisilla purkauksilla oli monitulkintainen tarkoitusperä. Miehet saattoivat olla vielä tässä vaiheessa avioliittoaikeissaan tosissaan ja huolissaan siitä, keneen naisten tunteet kohdistuivat.

Mustasukkaisten tiedustelujen avulla miehet mahdollisesti yrittivät myös vähätellä omaa rooliaan ja rauhoitella naista. Kaarle Kaarlenpoika oli päivännyt kirjeen talontytär Wilhelmina Hermannintyttärelle lokakuussa 1891, jolloin tämä oli jo synnyttänyt lapsen. Kaarle kertoi piirtävänsä

jonkun ratin sinuva kohtaan ja mitäs sinä oma Armani nyt olet tumannu ja miettinyt nistä rakkavuten Asijoista jotka on hyvin isosti otettavana sinulla kummanko päälle arpa lankija, uvenko vai vaanhanko. (JyMA Keuruun Tk 19.2.1892, § 196, liite A.)

Kaarle tunnusti, että

olen sen atellut ihan sytämmeni pohjasta [...] kitoksia kaiken teijän hellän rakkautenne etestä [...] Ettehän minä sinuva saa sinulla on mielessän se yksi muu parempi ja suottahan minä teillen taijan kirjotta [...] Enhän minä olis lullu tämä asijan näin ikävällen kohallen käyvä.

Suhteen loppumiseenkin Kaarle arveli tyytyvänsä,

Eihän minustakan silti tarvihte huolia jos Ei meijän rakkavus siihen sovellu. (JyMA Keuruun Tk 19.2.1892, § 196, liite A.)

Kirjeen maininnat rakkaudesta ja Wilhelminan syyllistäminen toisen miehen valinnasta asettuvat aivan toisenlaiseen perspektiiviin, kun otetaan huomioon että Kaarle oli jo aiemmin käytännössä hylännyt raskaana olleen Wilhelminan. Todistajanlausunnon mukaan hieman ennen lapsen syntymää he olivat sopineet lähtevänsä hakemaan kuulutuskirjaa pappilasta, mutta sovitun ajan tultua Kaarle oli juossut metsään pakoon, saanut siirrettyä pappila-matkaa viikolla eteenpäin, ja mennyt kihloihin ja myöhemmin naimisiin toisen naisen kanssa. (JyMA Keuruun Tk 19.2.1892, $\S$ 196.) Ei siis ihme, että Wilhelmina ei ollut enää innostunut Kaarlen kauniista sanoista, vaan halusi vain saada elatuksen lapselleen. 
Pasi Saarimäki: Nuorten miesten kirjeitse ohjailemat seurustelusuhteet 1800-luvun lopun 24 sisäsuomalaisella maaseudulla

[http://www.elore.fi/arkisto/2_14/saarimaki.pdf]

\section{YKSITYISKIRJEIDEN MERKITYS SEURUSTELUSUHTEILLE}

Edellisen luvun esimerkkipariskunnan, Wilhelmiinan ja Kaarlen suhde oli tyypillinen oikeustapausten virrassa. Mitä kirjeet sitten paljastavat aikakauden seurustelusuhteista ja seurustelukulttuurista? Kokonaisuudessaan tämän artikkelin aineisto tuo esiin aikakauden seurustelusuhteiden ja kulttuurin olleen monitahoista. Kirjeistä voi silti hahmottaa yhteneväisiä emotiiveja. Suhteiden alkuvaiheen kirjeissä korostuivat hellät rakkaudenilmaisut, tapaamisten sopimiset ja jopa toiveet kihlauskuulutusten hakemisesta. Nuoret seurustelivat selvästi keskenään, jolloin perinnäistavoilla, ulkopuolisilla henkilöillä ja yhteisön säännöillä oli toissijainen rooli. Tämä näkyy siinä, että aviolupausten antaminen - käytännössä kosiminen - ja kihlautuminen olivat kahdenkeskistä puuhaa. Naiset halusivat luottaa miesten kirjeissään kuvailemiin tunteisiin ja lupauksiin avioliitosta, koska naimattomaksi jäämistä pidettiin maaseutuyhteisössä kielteisenä asiana, ja odotetun avioliiton myötä mahdollista raskautta ei tarvinnut enää pelätä. Suhteet kuitenkin päättyivät ja avioliiton sijaan rakkauskirjeiden lähettäjät ja vastaanottajat päätyivät käräjille kamppailemaan lapsenelatuksesta. Raskaaksi tulemisen jälkeen miehet ilmaisivat kirjeissä pitkään vakuutteluja yhteisestä tulevaisuudesta ja tunteista naista kohtaan, mutta samoilla riveillä näkyi huoli raskaudesta ja lapsesta.

Raskaudesta huolimatta seurustelut eivät kuitenkaan johtaneet yhteisön odottamaan päätökseen, avioliittoon. Suhteiden kariutumisen syitä pöytäkirjat eivät suoraan paljasta, koska oikeus ei ollut kiinnostunut niistä. Lähes aina kysymys oli siitä, että mies päätti suhteen. Elatustapausten syytekirjelmissä naiset esittivät, että juuri raskaus ja lapsen syntymä olivat saaneet miehet hylkäämään heidät. On mahdollista, että tunteet viilentyivät seurustelun kestäessä, tai miehet olivat vakuuttaneet tunteitaan ja avioliittoaikeitaan vain seksin vuoksi. Ehkä avioliiton solmiminen taloudellisista syistä ei onnistunutkaan, kun sitä joutui raskauden ja lapsen syntymisen vuoksi miettimään aivan tosissaan. Toisaalta ongelmia suhteiden vakiintumisessa aiheuttivat myös suhteen ulkopuoliset ihmiset. Seurustelevien miesten epävarmuus naisten uskollisuudesta aiheutti mustasukkaisuutta ja väärinkäsityksiä. Alkuvaiheen kirjeiden romanttiset tunneilmaisut muuttuivat rauhoitteleviksi vakuutteluiksi, ja naiset päätyivät lopulta synnyttämään yksin avioliiton ulkopuolisen lapsen.

Muutamassa tapauksessa on mahdollista spekuloida sillä mahdollisuudella, että lopullisen päätöksen suhteen päättymisestä olisi tehnyt nainen, joka ei miehen kirjeitse esittämistä tunteiden vakuutteluista ja raskaudesta huolimatta olisi miestä enää huolinut. Lähdeaineisto ei anna mahdollisuutta tämän vaihtoehdon todentamiselle. Raskauteen ja jopa kihlaukseen johtaneen suhteen lopettamisesta vastasivat 1800-luvun 
Pasi Saarimäki: Nuorten miesten kirjeitse ohjailemat seurustelusuhteet 1800-luvun lopun 25 sisäsuomalaisella maaseudulla

[http://www.elore.fi/arkisto/2_14/saarimaki.pdf]

lopun maaseudulla käytännössä miehet, sillä aviottoman äidin sosiaalisesti ja taloudellisesti huonon tulevaisuudenkuvan vuoksi naimattomilla naisilla oli äärimmäisen suuri kynnys omatoimisesti katkaista tällaista suhdetta.

Kirjeillä oli suhteiden eri vaiheissa erilaisia merkityksiä seurustelukumppaneille. Tapauksissa, joissa seurustelukumppanit asuivat etäällä toisistaan, kirjeillä rakennettiin suhdetta. Kyseisellä ajalla kirjeiden lähettäminen oli verrattain harvinaista, joten niiden saaminen oli erikoista ja hienoa. Vaikka artikkelissa on keskitytty miesten kirjeisiin, suhteiden rakentumisessa kirjeiden avustuksella oli kyse dialogista, jossa toisena osapuolena olivat naiset omine kirjeineen. On myös hyvä pitää mielessä, että seurustelusuhteet eivät rakentuneet pelkästään kirjeiden varaan, mutta ne helpottivat ja edistivät sosiaalista kanssakäymistä.

Esitin johdannossa, että kirjeiden avulla miehet pyrkivät ohjaamaan suhdetta sen eri vaiheissa. Suhdetta edistivät ja sen kariutumista tai raskauden aiheuttamaa tilannetta toivat esiin kirjeiden tunteenilmaukset ja asiasisällöt. Suhteiden alkuvaiheissa miehet ohjasivat suhdetta kohti avioliittoa. Tämä tapahtui ensinnäkin kirjoittamalla kiintymyksen tunteista naiselle, tarkoituksena vakuuttaa tämä avioliittoaikeiden vakavuudesta. Toisekseen kirjeiden avulla oli mahdollista sopia kahdenkeskisistä tapaamisista, jotka edelleen syvensivät suhdetta.

Suhteen tässä vaiheessa kirjeistä välittyvät tunteet olivat positiivisia: miehet puhuivat hellästi rakkaudesta, romanttisesti kaipauksestaan ja korostivat pettymyksen ja ikävän tunteitaan, kun toista osapuolta ei ollut vähään aikaan tavattu tai tapaamiset peruuntuivat. Kirjeiden hyödyntäminen oli menestyksekästä, sillä suurin osa pariskunnista ehti olla ainakin epävirallisesti kihloissa keskenään.

Raskauden jälkeen miehet pyrkivät eri tavoin reagoimaan muuttuneeseen tilanteeseen. Jotkut vielä korostivat naista kohtaan kokemiaan tunteita, mikä voi kertoa avioliittohalukkuudesta tai sitten vain yrityksestä rauhoitella naisia. Toiset kirjoittivat aviottoman lapsen asemasta ja oman miehisen maineen uhatuksi joutumisesta, tai sitten vain esittivät mustasukkaisia syytöksiä naista kohtaan. Tässä vaiheessa kirjeissä ilmaistut tunteet vaihtelivat. Romanttisten rakkauden ilmausten lisäksi miehet jakoivat naisille lohduttavia sanoja ja korostivat ikävää ja kaipausta tätä kohtaan. Toisaalta kirjeisiin ilmestyi tummempia tunnesävyjä. Naisen raskaudesta saatettiin puhua ikävänä ja huolestumista aiheuttavana tilana, naisten levittämistä puheista närkästyttiin, ja lopulta oltiin mustasukkaisia mahdollisista kilpakosijoista.

Jos suhteen syventämisvaiheessa miesten ohjailuyritykset onnistuivat, loppuvaiheen kirjeillä ei voinut enää kieltää tai väistää todellisuutta. Lapsi 
Pasi Saarimäki: Nuorten miesten kirjeitse ohjailemat seurustelusuhteet 1800-luvun lopun 26 sisäsuomalaisella maaseudulla

[http://www.elore.fi/arkisto/2_14/saarimaki.pdf]

oli syntymässä tai jo syntynyt, mutta avioliitto ei syystä tai toisesta ollut mahdollinen. Naisten lähettämien kirjeiden sijaan miehet saivat seuraavaksi luettavakseen nimismiehen heille lähettämän haastekirjeen, jossa ilmoitettiin lastenelatusoikeudenkäynnin ensimmäinen käsittelypäivä.

\section{LÄHTEET}

\section{Tutkimusaineistot}

\section{Arkistoaineistot:}

Jyväskylän maakunta-arkisto (JyMA).

Jyväskylän Tuomiokunta, Keuruun käräjäkunta:

Varsinaisasiain pöytäkirjat, Syyskäräjät 1879-Syyskäräjät 1901. Niteet II Ca: $92-135$.

Välikäräjäin pöytäkirjat, Välikäräjät 1881-1900. Niteet I Cg: 9-28.

\section{Painetut lähteet:}

Ruotsin Valtakunnan Laki, Hyväksytty ja noudatettavaksi otettu valtiopäivillä vuonna 1734, Suomen Suuriruhtinasmaassa. Voimassaolevat osat, sekä 1 päivään heinäkuuta 1909 ilmestyneet säännökset ynnä liite. (RVL 1734 (1809). 4. painos. Helsinki: SKS. 1909.

Kirkkolaki Suomen suuriruhtinaanmaan evankelis-luterilaiselle kirkolle, annettu 6.p:nä Joulukuuta 1869, muutoksineen ja lisäyksineen 7 p:Itä kesäkuuta 1895. Asianomaisesti hyväksytty uusi suomenkielinen teksti sekä muutokset ja lisäykset v:Ita 1908 ynnä asialuettelo (KL 1869). Porvoo: Werner Söderström Osakeyhtiö. 1908.

Suomen Rikoslaki, annettu joulukuun 19 päivänä 1889. Muutoksineen ja lisäyksineen. Toimittanut A. E. Andersson (Rikoslaki 1889). Helsinki: Suomalaisen Kirjallisuuden seura. 1919.

\section{Kirjallisuus}

Anttila, Inkeri 1956: Alaikäisiin kohdistuneet siveellisyysrikokset ja niiden tekijät. Suomalaisen lakimiesyhdistyksen julkaisuja, A-sarja N:o 50. Helsinki: Suomalainen lakimiesyhdistys. 
Pasi Saarimäki: Nuorten miesten kirjeitse ohjailemat seurustelusuhteet 1800-luvun lopun 27 sisäsuomalaisella maaseudulla

[http://www.elore.fi/arkisto/2_14/saarimaki.pdf]

Apo, Satu 1995: Naisen väki: tutkimuksia suomalaisten kansanomaisesta kulttuurista ja ajattelusta. Helsinki: Hanki ja jää.

Apo, Satu 1998: "Ex cunno Come the Folk and Force". Consepts of Women's Dynamistic Power in Finnish-Karelian Tradition. - Apo, Satu, Nenola, Aili, Stark-Arola, Laura (eds.), Gender and Folklore. Perspectives on Finnish and Karelian Culture. Studia Fennica Folkloristica 4. Helsinki: FLS. 63-91.

Apo, Satu, Nenola, Aili, Stark-Arola, Laura (eds.) 1998: Gender and Folklore. Perspectives on Finnish and Karelian Culture. Studia Fennica Folkloristica 4. Helsinki: FLS.

Backman, Linda 2006: Kärlekshandel. Äktenskapsstrategier och giftermålsmönster inom det handlande borgerskapet vid 1800-talets början. - Historisk Tidskrift för Finland 91(2): 139-159.

Van Bavel, Jan 2001: Family Control, Bridal Pregnancy, and Illegitimacy. - Social Science History 25 (3): 449-479.

Bjurman, Eva Lis 1998: Catrines intressanta blekhet: unga kvinnors möten med de nya kärlekskraven 1750-1830. Stehag: Brutus Östlings bokförlag Symposion.

Bolin Hort, Per 1998: En Tråkig historia. Ogifta mödrar, deras barn och fattigvården I Simrishamn, 1870-1917. Linköping Studes in Arts and Sciense 175. Linköping: Tema Barn, Linköpings universitet.

Bound, Fay 2002: Writing the Self? Love and the Letter in England, c. 1660 - c. 1769 . - Literature \& History 11(1): 1-19.

Darrow, Margaret H. 1985: Popular concepts of marital choice in eighteenth century France. - Journal of Social History 19(2): 261272.

Dribe, Martin \& Lundh, Christer 2009: Status Homogamy in the Preindustrial Marriage Market: Partner Selection According to Age, Social Origin, and Place of Birth in Nineteenth-century Rural Sweden. - Journal of Family History 34(4): 387-406.

Elomaa, Hanna 1995: Porvarillista rakkautta: Oskar ja Mili Hultmanin tarina (1886-1892). Mäkinen, Katriina ja Rossi, Leena (toim.), Rakkautta, ihanteita ja todellisuutta. Retkiä suomalaiseen mikrohistoriaan. Turun yliopiston täydennyskoulutuskeskuksen julkaisuja A: 42. Turku: Turun yliopiston täydennyskoulutuskeskus. 22-63.

Frost, Ginger S. 1995: Promises Broken. Courtship, Class, and Gender in Victorian England. Victorian Literature and Culture Series. Charlottesville: University Press of Virginia. 
Pasi Saarimäki: Nuorten miesten kirjeitse ohjailemat seurustelusuhteet 1800-luvun lopun 28 sisäsuomalaisella maaseudulla

[http://www.elore.fi/arkisto/2_14/saarimaki.pdf]

Frykman, Jonas 1977: Horan i bondesämhället. Lund: Liber läromedel.

Gaunt, David 1996: Familjeliv i Norden. Södertälje: Gudlund. [1983]

Gillis, John R. 1986: For better for worse: British marriages, 1600 to the present. New York: Oxford University Press.

Gillis, John R. 1988: From ritual to romance: Toward an alternative history of love. - Stearns, Carol Z, Stearns, Peter N (eds.), Emotion and Social Change. Toward a New Psycohistory. New York: Holmes \& Meier. 97-122.

Hakamies, Pekka 1998: Rakkaus ja rakastelu sananparsissa. - Pöysä, Jyrki ja Siikala, Anna-Leena (toim.), Amor, Genus \& Familia. Kirjoituksia kansanperinteestä. Tietolipas 158. Helsinki: SKS. 216-229.

Hakapää, Jyrki 2013: Arkkiveisut. Lauletun ja kirjallisen kohtaaminen. Laitinen, Lea ja Mikkola, Kati (toim.), Kynällä kyntäjät. Kansan kirjallistuminen 1800-luvun Suomessa. Suomalaisen Kirjallisuuden Seuran Toimituksia 1370. Helsinki: SKS. 221-252.

Heikinmäki, Maija-Liisa 1981: Suomalaiset häätavat. Helsinki: Otava.

Heikkinen, Kaija 2003: Sukupuolen näkökulma perinteentutkimuksessa. - Turunen, Risto ja Roivas, Marianne (toim.), Mikä ero? Kaksikymmentä kirjoitusta yhteiskunnasta, kulttuurista ja sukupuolesta. Helsinki: SKS. 139-155.

Helsti, Hilkka 2000: Kotisynnytysten aikaan. Etnologinen tutkimus äitiyden ja äitiysvalistuksen konflikteista. Suomalaisen Kirjallisuuden Seuran Toimituksia 785. Helsinki: SKS.

Hemmer, Ragrar 1967: Suomen oikeushistorian oppikirja II: Perheoikeuden, perintöoikeuden ja testamenttioikeuden historia. Helsinki: Lainopillisen ylioppilastiedekunnan kustannustoimikunta.

Huhtala, Liisi 1996: Arkkiveisu kirjallisuuden tutkimuksen näkökulmasta. - Tuija Laine (toim.), Kirjahistoria. Johdatus vanhan kirjan tutkimukseen. Suomalaisen Kirjallisuuden Seuran Toimituksia 647. Helsinki: SKS. 237-251.

Hyyrö, Tuula 2011: Alkuopetus kiertokoulusta alakansakouluun. Heikkinen, Anja, Leino-Kaukiainen, Pirkko (toim.), Valistus ja kirkonpenkki. Kasvatus ja koulutus Suomessa 1860-luvulta 1960luvulle. Suomen kasvatuksen ja koulutuksen historia II. Suomalaisen Kirjallisuuden Seuran Toimituksia 1266:2, Tiede. Helsinki: SKS. 327-329, 332-347, 351.

Håkanson, Sigrid 1999: "då skall han taga henne till äkta..." Oäkta födslar, äktenskapsmarknad och giftermålssystem i Östsverige och 
Pasi Saarimäki: Nuorten miesten kirjeitse ohjailemat seurustelusuhteet 1800-luvun lopun 29 sisäsuomalaisella maaseudulla

[http://www.elore.fi/arkisto/2_14/saarimaki.pdf]

Västsverige 1750-1850. Studier i Stads- och Kommunhistoria 17. Stockholm: Stads och kommunhistoriska institutet.

Hökkä, Tuula 2010: Rakkauden liitto=kirjeitä. - Enwald, Liisa, Hökkä, Tuula (toim.), Virren virtaa. Veisattu runo ennen ja nyt. Helsinki: Kansanvalistusseura. 121-160.

Jarrick, Arne 1997: Kärlekens makt och tårar - en evig historia. Stockholm: Norstedt.

Jauhiainen, Marjatta 1990: "Viattomuus on naisen ensimmäinen kaunistus". Naisen synti uskomustarinoissa. - Nenola, Aili ja Timonen, Senni (toim.), Louhen sanat: kirjoituksia kansanperinteen naisista. Suomalaisen Kirjallisuuden Seuran Toimituksia 520. Helsinki: SKS. 127-138.

Kauranen, Kaisa (toim.) 2009: Työtä ja rakkautta. Kansanmiesten päiväkirjoja 1834-1937. Kansanelämän kuvauksia 75. Helsinki: SKS.

Kauranen, Kaisa 2013: Mitä ja miksi kansa kirjoitti? - Laitinen, Lea ja Mikkola, Kati (toim.), Kynällä kyntäjät. Kansan kirjallistuminen 1800-Iuvun Suomessa. Suomalaisen Kirjallisuuden Seuran Toimituksia 1370. Helsinki: SKS. 19-54.

Keravuori, Kirsi 2012: Itseoppineet kirjoittajat, kirjeenvaihdon kulttuuri ja kirjeet egodokumentteina.Tutkimus Janssonin laivuriperheen kirjeenvaihdosta 1860- ja 1870-luvulla. Suomen historian lisensiaatintutkimus. Turku: Turun yliopisto.

Kietäväinen-Sirén, Hanna 2011: "The warm water in my heart" - The meanings of love among the Finnish country population in the second half of the 17th century. - The History of the Family 16(1): 47-61.

King, Steve 2010: Love, Religion and Power in the Making of Marriages in Early Nineteenth-Century Rural Industrial Lancashire. - Rural History 21(1): 1-26.

Knuutila, Jyrki 1990: Avioliitto oikeudellisena ja kirkollisena instituutiona Suomessa vuoteen 1629. Suomen Kirkkohistoriallisen Seuran Toimituksia 151. Helsinki: Suomen Kirkkohistoriallinen seura.

Knuuttila, Seppo ja Kupiainen, Tarja 2003: Haaveissa vainko oot mun? Kansanrunojen epätyydyttävät parisuhteet. - Turunen, Risto ja Roivas, Marianne (toim.), Mikä ero? Kaksikymmentä kirjoitusta yhteiskunnasta, kulttuurista ja sukupuolesta. Helsinki: SKS. 156181. 
Pasi Saarimäki: Nuorten miesten kirjeitse ohjailemat seurustelusuhteet 1800-luvun lopun 30 sisäsuomalaisella maaseudulla

[http://www.elore.fi/arkisto/2_14/saarimaki.pdf]

Korhonen, Anu 2005: Constructing Emotion in a Culture of Hierarchies. Anu Korhonen ja Kirsi Tuohela (eds.), Time Frames. Negotiating Cultural History. Kulttuurihistoria 1. Turku: Kulttuurihistorian laitos, Turun yliopisto. 57-73.

Korpiola, Mia 2009: Between Bethothal and Bedding. Marriage Formation in Sweden 1200-1600. Leiden: Brill.

Kotilainen, Sofia \& Saarimäki, Pasi 2013: Isäehdokkaat hiillostettavina - Paikallisyhteisö aviottoman äidin tukena 1800-luvun lopun sisäsuomalaisella maaseudulla. - Eilola, Jari, Moilanen, Laura-Kristiina (toim.), Yhteisöllisyyden perintö. Tutkimuksia yhteisöistä eri vuosisadoilla. Historiallinen Arkisto 139. Helsinki: SKS. 114-146.

Kuismin, Anna \& Driscoll, M. J. (eds.) 2013: White Field, Black Seeds. Nordic Literacy Practices in the Long Nineteenth Century. Studia Fennica Litteraria 7. Helsinki: FLS.

Kälvemark, Ann-Sofie 1977: Att vänta barn när man gifter sig. Föräktenskapliga förbindelser och giftermålsmönster i 1800-talets Sverige. - Historisk Tidskrift (Svensk), 97: 181-199.

Kälvemark, Ann-Sofie 1978: Hotet mot familjen. Den ogifta modern i Sverige i historisk perspektiv. - Historisk Tidskrift (Svensk), 98: 83-101.

Kälvemark, Ann-Sofie 1983: Kommer familjen att överleva? Historiska aspekter på äktenskap och familj idet svenska samhället. - Norman, Hans (red.), Den utsatta familjen. Liv, arbete och samlevnad $i$ olika nordiska miljöer under de senaste tvåhundra åren. Kristiansand: LTs förlag. 13-20.

\section{Lahtinen, Anu, Leskelä-Kärki, Maarit, Vainio-Korhonen, Kirsi \&} Vehkalahti, Kaisa 2011: Kirjeiden uusi tuleminen. - LeskeläKärki, Maarit, Lahtinen, Anu, Vainio-Korhonen, Kirsi (toim.), Kirjeet ja historiantutkimus. Historiallinen arkisto 134. Helsinki: SKS. 9-27.

Laine, Esko M. \& Laine, Tuija 2010: Kirkollinen kansanopetus. Hanska, Jussi, Vainio-Korhonen, Kirsi (toim.), Huoneentaulun maailma. Kasvatus ja koulutus Suomessa keskiajalta 1860-luvulle. Suomen kasvatuksen ja koulutuksen historia I. Suomalaisen Kirjallisuuden Seuran Toimituksia 1266: I, Tiede. Helsinki: SKS. 258312.

Laitinen, Erkki 1988. Väestö ja yhteiskunta. - Jokipii, Mauno (toim.), Keski-Suomen historia 2. Jyväskylä: Keski-Suomen maakuntaliitto. 64-138. 
Pasi Saarimäki: Nuorten miesten kirjeitse ohjailemat seurustelusuhteet 1800-luvun lopun 31 sisäsuomalaisella maaseudulla

[http://www.elore.fi/arkisto/2_14/saarimaki.pdf]

Laitinen, Lea \& Mikkola, Kati (toim.) 2013: Kynällä kyntäjät. Kansan kirjallistuminen 1800-luvun Suomessa. Suomalaisen Kirjallisuuden Seuran Toimituksia 1370. Helsinki: SKS.

Laitinen, Lea 2013: Näytelmät. Näyttämölle kirjoitettu dialogi. - Laitinen, Lea ja Mikkola, Kati (toim.), Kynällä kyntäjät. Kansan kirjallistuminen 1800-luvun Suomessa. Suomalaisen Kirjallisuuden Seuran Toimituksia 1370. Helsinki: SKS. 257-298.

Langhamer, Claire 2007: Love and courtship in mid-twentieth-century England. - Historical Journal 50(1): 173-196.

Leino-Kaukiainen, Pirkko 2007: Suomalaisten kirjalliset taidot autonomian kaudella. - Historiallinen aikakauskirja 105(4): 420-440.

Leino-Kaukiainen, Pirkko 2011: "Nyt lasken minä pännäni tämä viherjäisen paperin päälle". Nuoren sotilaan kirjeitä 1800-luvun lopulta. - Leskelä-Kärki, Maarit, Lahtinen, Anu, Vainio-Korhonen, Kirsi (toim.), Kirjeet ja historiantutkimus. Historiallinen arkisto 134. Helsinki: SKS. 194-219.

Lennartsson, Malin 1999: I säng och säte: relationer mellan kvinnor och män i 1600-talets Småland. Bibliotheca historica Lundensis 92. Lund: Lund University Press.

Losman, Beata 1982: Förtryct eller jämställdhet? Kvinnorna och äktenskap i Västsverige omkring 1840. - Historisk Tidskrift (Svensk), 102: 291-318.

Lukkarinen, J. 1933: Suomalaisten naimatapoja: aineksia suomalaisten kansojen avioliiton historiaan. Suomalaisen Kirjallisuuden Seuran Toimituksia 186, Kansatieteellisiä kuvauksia IV. Helsinki: SKS.

Lyons, Martyn (ed.) 2007: Ordinary Writings, Personal Narratives: Writing Practices in 19th and early 20th-Century Europe. Bern: Peter Lang.

Lyons, Martyn 2013: A New History from Below? - Kuismin, Anna \& Driscoll, M. J. (eds.), White Field, Black Seeds. Nordic Literacy Practices in the Long Nineteenth Century. Studia Fennica Litteraria 7. Helsinki: FLS. 14-29.

Lystra, Karen 1989: Searching the Heart: Women, Men, and Romantic Love in Nineteenth-Century America. New York: Oxford University Press.

Löfström, Jan 1999: Sukupuoliero agraarikulttuurissa: 'Se nyt on vaan semmonen'. Suomalaisen Kirjallisuuden Seuran Toimituksia 757. Helsinki: SKS. 
Pasi Saarimäki: Nuorten miesten kirjeitse ohjailemat seurustelusuhteet 1800-luvun lopun 32 sisäsuomalaisella maaseudulla

[http://www.elore.fi/arkisto/2_14/saarimaki.pdf]

MacFarlane, Alan 1986: Marriage and Love in England 1300-1840.

Oxford: Blackwell.

Makkonen, Anna 2002: Karheita kertomuksia. Itseoppineiden elämäkertoja 1800-luvun Suomesta. Helsinki: SKS.

Miettinen, Tiina 2012: Ihanteista irrallaan. Hämeen maaseudun nainen osana perhettä ja asiakirjoja 1600-luvun alusta 1800-luvun alkuun. Acta Universitatis Tamperensis 1756. Acta Electronica Universitatis Tamperensis 1229. E-versio: http://urn.fi/urn:isbn:978-951-448887-0.

De Munck, Bert 2004: Free choice, modern love, and dependence: marriage of minors and rapt de séduction in the Austrian Netherlands. - Journal of Family History 29(2): 183-205.

Mönkkönen, Mauri 1983: Vanhan Ruoveden historia, osa 3, 2: Multian historia 1866-1975. Multia: Multian kunta/Multian Seurakunta.

Nenola, Aili 1990: Sukupuoli, kulttuuri ja perinne. - Nenola, Aili ja Timonen, Senni (toim.), Louhen sanat: kirjoituksia kansanperinteen naisista. Suomalaisen Kirjallisuuden Seuran Toimituksia 520. Helsinki: SKS. 11-23.

Niekka, Ilse \& Petrelius, Päivi 1993: Suomalainen vanhapiikuus: tutkielma naisen naimattomuuden kulttuurisesta määrittelystä. Jyväskylän yliopiston yhteiskuntapolitiikan laitoksen työpapereita, 77. Jyväskylä: Jyväskylän yliopisto.

Nieminen, Armas 1951: Taistelu sukupuolimoraalista: avioliitto ja seksuaalikysymyksiä suomalaisen hengenelämän ja yhteiskunnan murroksessa säätyajoilta 1910-luvulle. Väestöpoliittisen tutkimuskeskuksen julkaisuja Sarja A: 6. Helsinki: WSOY.

Nieminen, Armas 1993: Suomalaisen aviorakkauden ja seksuaalisuuden historia: avioliitto ja seksuaalikysymyksiä suomalaisen hengenelämän ja yhteiskunnan murroksessa säätyajoilta 1910-luvulle. Väestöntutkimuslaitoksen julkaisusarja nro 27. Helsinki: Väestöntutkimuslaitos, Väestöliitto.

Nordlund, Taru 2005: Miten ja miksi kansa alkoi kirjoittaa? Suomalaisten talonpoikien kirjeitä 1800-luvun alusta. - Huttunen, Sirpa ja Nuolijärvi, Pirkko (toim.), Tahdon sanoa. Kirjoituksia kielen ja perinteen voimasta. Suomalaisen Kirjallisuuden Seuran Toimituksia 1035. Helsinki: SKS. 51-79.

Nousiainen, Mervi 1990: Salaisen teon julkinen pohdinta. Lastenmurhatarinat kulttuurisena puheena. - Nenola, Aili ja Timonen, Senni (toim.), Louhen sanat: kirjoituksia kansanperinteen naisista. Suo- 
Pasi Saarimäki: Nuorten miesten kirjeitse ohjailemat seurustelusuhteet 1800-luvun lopun 33 sisäsuomalaisella maaseudulla

[http://www.elore.fi/arkisto/2_14/saarimaki.pdf]

malaisen Kirjallisuuden Seuran Toimituksia 520. Helsinki: SKS. 161-168.

Paasio, Marja (toim.) 2004: Pilvihin on piian nännit: Suomen kansan seksiperinnettä. Helsinki: Otava.

Pehkonen, Erkka 2013: "Poikasi täältä jostakin". Narratiiviset resurssit, diskurssit ja luovuus kirjoittaen kerrotuissa identiteeteissä jatkosodan aikaisissa kirjeissä. Jyväskylä Studies in Humanities 217. Jyväskylä: Jyväskylän yliopisto.

Piela, Ulla 1990: Lemmennostoloitsujen nainen. - Nenola, Aili ja Timonen, Senni (toim.), Louhen sanat: kirjoituksia kansanperinteen naisista. Suomalaisen Kirjallisuuden Seuran Toimituksia 520. Helsinki: SKS. 214-223.

Pohjola-Vilkuna, Kirsi 1995: Eros kylässä - Maaseudun luvaton seksuaalisuus vuosisadan vaihteessa. Suomi 177. Helsinki: SKS.

Pöysä, Jyrki 1997: Jätkän synty. Tutkimus sosiaalisen kategorian muotoutumisesta suomalaisessa kulttuurissa ja itäsuomalaisessa metsätyöperinteessä. Suomalaisen Kirjallisuuden seuran Toimituksia 669. Helsinki: SKS.

Raitasalo, Pirkko 2004: "Katsel ain minnuu". Kirkonpenkiltä tanssilattialle. Nuorison tutustuminen ja seurustelu Muolaassa karjalan kannaksella 1910-luvulta vuoteen 1939. Omakustanne.

Reddy, William M. 1997: Against Constructionism. The Historical Ethnography of Emotions. - Current Anthropology 38(3): 327-351.

Reddy, William M. 2001: The Navigation of Feeling: a Framework for the History of Emotions. Cambridge University Press, Cambridge.

Ritamies, Marketta 2006: Sinappikylvystä ehkäisypilleriin. Suomalaisen perhesuunnittelun historia. Väestöntutkimuslaitoksen julkaisusarja D 44/2006. Helsinki: Väestöntutkimuslaitos, Väestöliitto.

Rothman, Ellen K. 1982: Sex and Self-Control: Middle-Class Courtship in America, 1770-1870. - Journal of Social History 15(3): 409-409.

Saarimäki, Pasi 2006: Avioliitto-odotuksiin kytkeytyvät naimattomien ihmisten seksuaalisuus ja sen seuraukset - Normit, performatiivisuus ja sukupuoli keskisuomalaisessa maaseutuyhteisössä ja käräjillä 1800-luvun jälkipuoliskolla. Suomen historian julkaisematon lisensiaatintyö. Jyväskylä: Jyväskylän yliopisto, Historian ja etnologian laitos. E-versio: http://urn.fi/URN: NBN:fi:jyu-200752. 
Pasi Saarimäki: Nuorten miesten kirjeitse ohjailemat seurustelusuhteet 1800-luvun lopun 34 sisäsuomalaisella maaseudulla

[http://www.elore.fi/arkisto/2_14/saarimaki.pdf]

Saarimäki, Pasi 2008: Maaseudun aviottomien äitien toimintastrategiat käräjillä 1800-luvun lopulla. - Historiallinen Aikakauskirja, 106(2): 152-164.

Saarimäki, Pasi 2010: Naimisen normit, käytännöt ja konfliktit. Esiaviollinen ja aviollinen seksuaalisuus 1800-luvun lopun keskisuomalaisella maaseudulla. Jyväskylä Studies in Humanities 138. Jyväskylä: Jyväskylän yliopisto. E-versio: http://urn.fi/URN:ISBN:978-951-393830-7.

Saarimäki, Pasi 2014: Legislative and judicial effects of forbidden sexuality on engagements and marriages in late nineteenth-century Central Finland. - Matikainen, Olli, Lidman, Satu (eds.), Morality, Crime and Social Control in Europe 1500-1900. Studia Historica 84. Helsinki: FLS. 107-126.

Sarmela, Matti 1969: Reciprocity Systems of the Rural Society in the Finnish-Karelian Culture Area: With Special Reference to Social Intercourse. Academia Scientiarum Fennica FF Communications Vol. 88:1. No.207. Helsinki: Suomalainen Tiedeakatemia.

Sarmela, Matti (toim.) 1981: Pohjolan häät. Helsinki: SKS.

Seutu, Katja 2013: Novellit. Kirjallistumisen merkit kansankirjoittajien novelleissa. - Laitinen, Lea ja Mikkola, Kati (toim.), Kynällä kyntäjät. Kansan kirjallistuminen 1800-luvun Suomessa. Suomalaisen Kirjallisuuden Seuran Toimituksia 1370. Helsinki: SKS. 304-332.

Shorter, Edvard 1975: The Making of the Modern Family. New York: Basic Books.

Stearns, Peter \& Stearns, Carl Z. 1985: Emotionology: Clarifying the History of Emotions and Emotional Standards. - The American Historical Review 90(4): 813-836.

Szreter, Simon \& Fisher, Kate 2010: Sex Before the Sexual Revolution. Intimate life in England 1918-1963. Cambridge: Cambridge University Press.

Stark-Arola, Laura 1998: Magic, Body and Social Order. The Construction of Gender Through Women's Private Rituals in Traditional Finland. Studia Fennica Folkloristica 5. Helsinki: FLS.

Stone, Lawrence 1979: The Family, Sex and Marriage In England 15001800. Harper Torchbooks. New York: Harper \& Row.

Tarkka, Lotte 2005: Rajarahvaan laulu. Tutkimus Vuokkiniemen kalevalamittaisesta runokulttuurista 1821-1921. Suomalaisen Kirjallisuuden Seuran Toimituksia 1033. Helsinki: SKS. 
Pasi Saarimäki: Nuorten miesten kirjeitse ohjailemat seurustelusuhteet 1800-luvun lopun 35 sisäsuomalaisella maaseudulla

[http://www.elore.fi/arkisto/2_14/saarimaki.pdf]

Taussi Sjöberg, Marja 1988: Skiljas. Trolovning, äktenskap och skilsmässa i Norrland på 1800-talet. Södertälje: Författarförlaget.

Telste, Kari 1999: The Performative Magic of Promises. Courtship as Ritual in Norwegian Popular Culture at the End of the Nineteenth Century. - Ethnologica Scandinavica 29: 84-96.

Tepora, Tuomas 2012: Neurotieteiden haaste tunteiden historialle. Historiallinen aikakauskirja 110(3): 322-340.

Tommila, Päiviö 1979: Jyväskylän sanomalehtien kaunokirjallinen sisältö 1871-1917. - Suomen sanomalehdistön historia -projekti (toim.), Runoutta ja nurkkaromaaneja. Sanomalehdistö kaunokirjallisuuden julkaisijana ennen vuotta 1917. Suomen Sanomalehdistön Historia projektin julkaisuja N:o 14. Helsinki: Suomen sanomalehdistön historia -projekti. 2-12.

Vakimo, Sinikka 2001: Paljon kokeva, vähän näkyvä. Tutkimus vanhaa naista koskevista kulttuurisista käsityksistä ja vanhan naisen elämänkäytännöistä. Suomalaisen Kirjallisuuden Seuran Toimituksia 818. Helsinki: SKS.

Vihola, Teppo 1983: Vanhan Ruoveden historia, osa 3, 3, 1: Keuruun ja Pihlajaveden historia 1860-1917. Keuruu: Keuruun ja Pihlajaveden historiatoimikunta.

Virtanen, Leea 1990: Huoraksi nimittely suomalaisessa perinteessä. Nenola, Aili ja Timonen, Senni (toim.), Louhen sanat: kirjoituksia kansanperinteen naisista. Suomalaisen Kirjallisuuden Seuran Toimituksia 520. Helsinki: SKS. 139-160.

Wikman, K. Rob. V. 1937: Die Einleitung der Ehe. Eine vergleichende ethno-soziologische Untersuchung über die Vorstufe der Ehe in den Stten des schwedischen Volkstums. Acta Academiae Aboensins. Series A, Humaniora. Helsingfors: Åbo Akademi.

Filosofian tohtori Pasi Saarimäki työskentelee tutkijatohtorina Suomen historian oppiaineessa Historian ja etnologian laitoksella, Jyväskylän yliopistossa. Hänen tutkimusintressinsä ulottuvat aviottomaan syntymään, avioliittoon ja avioeroihin 1800-Iuvun lopun ja 1900-Iuvun alun Suomessa. Hän on julkaissut väitöskirjan Naimisen normit, käytännöt ja konfliktit. Esiaviollinen ja aviollinen seksuaalisuus 1800-luvun lopun keskisuomalaisella maaseudulla (2010) ja ollut yhtenä toimittajana antologiassa Lapsi matkalla maailmaan. Historiallisia ja kulttuurisia näkökulmia syntymään (2012). 
Pasi Saarimäki: Nuorten miesten kirjeitse ohjailemat seurustelusuhteet 1800-luvun lopun 36 sisäsuomalaisella maaseudulla

[http://www.elore.fi/arkisto/2_14/saarimaki.pdf]

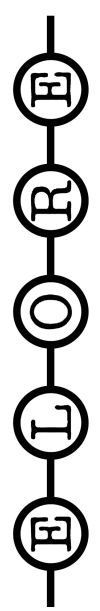

